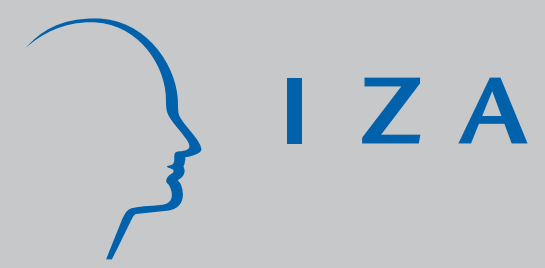

IZA DP No. 9508

The Relationship Between Establishment Training and the Retention of Older Workers: Evidence from Germany

Peter Berg

Mary K. Hamman

Matthew M. Piszczek

Christopher J. Ruhm

November 2015 


\title{
The Relationship Between Establishment Training and the Retention of Older Workers: Evidence from Germany
}

\author{
Peter Berg \\ Michigan State University \\ Mary K. Hamman \\ University of Wisconsin La Crosse \\ Matthew M. Piszczek \\ University of Wisconsin Oshkosh \\ Christopher J. Ruhm \\ University of Virginia and IZA
}

Discussion Paper No. 9508

November 2015

\author{
IZA \\ P.O. Box 7240 \\ 53072 Bonn \\ Germany \\ Phone: +49-228-3894-0 \\ Fax: +49-228-3894-180 \\ E-mail: iza@iza.org
}

\begin{abstract}
Any opinions expressed here are those of the author(s) and not those of IZA. Research published in this series may include views on policy, but the institute itself takes no institutional policy positions. The IZA research network is committed to the IZA Guiding Principles of Research Integrity.

The Institute for the Study of Labor (IZA) in Bonn is a local and virtual international research center and a place of communication between science, politics and business. IZA is an independent nonprofit organization supported by Deutsche Post Foundation. The center is associated with the University of Bonn and offers a stimulating research environment through its international network, workshops and conferences, data service, project support, research visits and doctoral program. IZA engages in (i) original and internationally competitive research in all fields of labor economics, (ii) development of policy concepts, and (iii) dissemination of research results and concepts to the interested public.
\end{abstract}

IZA Discussion Papers often represent preliminary work and are circulated to encourage discussion. Citation of such a paper should account for its provisional character. A revised version may be available directly from the author. 
IZA Discussion Paper No. 9508

November 2015

\section{ABSTRACT}

\section{The Relationship Between Establishment Training and the Retention of Older Workers: Evidence from Germany}

In the coming years, a substantial portion of Germany's workforce will retire, making it difficult for businesses to meet human capital needs. Training older workers may be a successful strategy for managing this demographic transition. This study examines relationships between establishment training programs, wages, and retirement among older men and women. Using unique matched establishment-employee data from Germany, the authors find that when establishments offer special training programs targeted at older workers, women and especially lower wage women - are less likely to retire. Results suggest this relationship may be due to greater wage growth. For men, findings suggest establishment offer of inclusion in standard training programs may improve retention of low wage men, but analysis of pre-existing differences in establishment retirement patterns suggests this relationship may not be causal. Our research suggests targeted training programs likely play an important role in retaining and advancing careers of low wage older women.

JEL Classification: J20, J24, J26

Keywords: $\quad$ workforce training, retirement, establishment training

Corresponding author:

Christopher J. Ruhm

Frank Batten School of Leadership and Public Policy

University of Virginia

204 Garrett Hall, 235 McCormick Rd.

P.O. Box 400893

Charlottesville, VA 22904-4893

USA

E-mail: ruhm@virginia.edu 
The aging of populations in many developed countries has significant implications for working populations and the age composition of workforces within organizations. Driven primarily by increased life expectancy and declining birth rates, these demographic trends are consistent across developed economies (Danson 2007). Germany in particular is Europe's “first and biggest test of the problems caused by an ageing and declining population" and is predicted to lose five million workers due to aging over the next 15 years (a $12.5 \%$ decline), with immigration and new entry into the labor force by younger workers expected to fill only a small portion of this gap (Elliott \& Kollewe 2011). Germany's overall population will shrink $18.8 \%$ by 2060 (Eurostat 2011), and the working age population (15-64 years old) could fall by $35 \%$ (Wanger, Weber, \& Fuchs 2013). By the end of the current decade workers over age 50 will constitute $40 \%$ of the labor force (Buss \& Kuhlmann 2013). As the largest economy in Europe, Germany's continued economic success is critical to Europe and the global economy. With an unemployment rate under $6 \%$, an aging population, and a shrinking labor force, German firms must confront how they develop and make use of the knowledge, skills, and abilities of their older workers.

Facing an aging workforce, German policymakers have encouraged people to work longer by gradually raising the age at which workers can obtain full pension benefits (Börschsupan \& Wilke 2003). At the same time, German employers are making use of various human resource practices to discourage early retirements or extend working lives. For example, German corporation BASF has launched the "Generations@Work” initiative, engaging its employees in life-long training, human resource development, health management, ergonomics, work-life balance, and flexible working hours (Blau 2011). Agreements negotiated between the chemical industry and the industry trade union include a "demography fund" to support a variety of 
practices related to management of older workers, including training. Yet, there is limited research on the role workplace policies and practices play in encouraging or discouraging longer work lives or about the mechanisms through which such practices operate (Dietz \& Walwei 2011; Paullin \& Whetzel 2012; Schlick, Frieling, \& Wegge 2013).

This paper focuses on the relationship between employer provided training and the retention and wages of older workers. The few previous studies examining these relationships obtain inconsistent findings and several important questions remain regarding this link. First, what is the mechanism through which training promotes longer working lives? There are a variety of theories that are used to explain this relationship, including human capital theory and psychological theories about changing work motives over the life cycle. We expand these perspectives by arguing that training's effect on the retention of older workers will vary across the wage distribution. Second, establishments that offer training to their older workers may adopt different approaches to training delivery. They could focus on involving their older workers in the standard training programs offered to the rest of their workforce, or they could create targeted training programs especially designed for older workers. Is one better than the other for improving retention? Third, to what extent does the effect of training on retention differ by gender? There are gender differences in labor market experiences and acquisition of human capital over the life-cycle, suggesting that the response to training near the end of one's working life may also differ between men and women.

We use data from the 2002, 2006, and 2008 Linked Employer-Employee Dataset (LIAB) of the German Institute for Employment Research (IAB), which combines survey data for a large, stratified random sample of German establishments with social security records for all 
establishment employees covered by the social security system: approximately $80 \%$ of the German work force.

\section{Literature Review}

\section{Training and retention of older workers: Existing evidence}

Studies across the age spectrum show a positive link between training and retention in the overall workforce (Hausknecht \& Trevor 2010; Heavey, Holwerda, \& Hausknecht 2013), but the few empirical studies focused on older workers have yielded conflicting results. Picchio and van Ours (2012), using data from 7,257 individuals from 1996-2001 in the European Community Household Panel, found that training led to greater worker retention in the Netherlands for workers aged 50-64. Herrbach, Mignonac, Vandenberghe, and Negrini (2009) use individual survey data from a sample of 514 late career managers to examine the relationship between training and retirement timing and also found a positive relationship between training and retention. Similarly, in a study of older professionals and nurses, Armstrong-Stassen and Ursel (2009) found that employer engagement in training and development practices negatively influenced workers' intention to turnover. Furthermore, they found that this relationship was partly mediated by perceived organizational support.

Using the European Household Panel, Fourage and Schils (2009) observed that training participation rates were positively associated with labor market participation rates in Europe, but that some early retirement schemes discouraged training participation and that this relationship varied considerably by country. In a study of older Dutch public sector employees, Montizaan, Coervers, and De Grip (2010) found that employees who recently experienced an increase in pensionable age were more likely to participate in training. Boockmann, Fries, and Goebel 
(2012) found no relationship between either standard or specific training on the exit rates of 4065 year old employees. Similarly, Kristensen (2012) concluded there is only a small relationship between general training through the lifespan and working life duration, and argued it was not large enough to justify government-funded training programs.

Many of the previous studies have limitations that may explain some of the conflicting findings and why understanding the relationship between training and retention of older workers is difficult. Picchio and van Ours (2012) measure training as whether or not the worker participated in firm training the previous year. Therefore, their analysis provides an estimate of the effect of training among the trained; however this estimate misses any workers who may have retired to avoid the training. Herrbach, Mignonac, Vandenberghe, and Negrini (2009) use a measure of training availability but their measure confounds the availability of any sort of training with the efficacy of the training. ${ }^{1}$ The analysis from Armstrong-Stassen and Ursel (2009) focused only on managerial, professional, and nursing occupations. In addition, they do not measure training or retirement directly. They rely on employee perceptions of whether their organization is currently engaged in training activities and employees' intention to keep working.

Boockmann, Fries, \& Goebel (2012) used a smaller version of the LIAB dataset that was limited to a random draw of 300 establishments. Although they found no relationship between establishment training and employee retention, they do not control for the overall rate of training participation among workers within the establishment. This may be an important omission because firms that train older workers may also have higher rates of training throughout the

\footnotetext{
${ }^{1}$ Respondents use a 5 point Likert scale to rate the availability of training opportunities that are "adapted to their needs", "extend their computer skills", "develop their management skills", and "continuously update their skills." But respondents are not asked to rate the availability of any training opportunities. Therefore, it is possible that respondents who were offered ineffective training or training that did not address the specific skills asked about in the survey would be coded in the same way as respondents who did not receive any training opportunities. Furthermore, the sample consisted only of managers and the relationship between training practices and retention behavior may vary by occupation.
} 
organization, offer better quality training, or be more invested in employee development in general. Moreover, this study does not investigate the mechanisms through which training is thought to affect older worker retention.

Our work addresses gaps in this literature in several ways. We use a broader representative sample of establishments with greater statistical power, incorporate controls for the amount of training participation occurring throughout the establishment workforce, investigate potential differences in effects by gender, and focus on discerning the mechanism by which training affects older worker retention. With regard to this last point, we examine joint effects of training practices, and how they may operate in conjunction with other establishment practices for older workers. In addition, we explore wages as a likely mechanism for explaining the relationship between training and retention of older workers.

\section{Establishment Training Practices and Other Practices for Older Workers}

Establishments that train their older workers face a choice. They can offer programs that include older workers in a standard training program designed for their entire workforce, offer targeted training programs, or use some combination of these two delivery strategies. This decision may influence both the effectiveness of the training itself and any relationship with retention.

Psychological research indicates that training programs vary in effectiveness from one individual to another (Ford \& Oswald 2003) and that training interventions are more effective when designed specifically for individuals or groups of similar individuals (Beier 2012). Older workers may benefit more from some training methodologies than from others (Callahan, Kiker, $\&$ Cross 2003). As people age, they experience a reorganization of traits and skills: cognitive processing speed slows whereas knowledge-related abilities grow (Kanfer \& Ackerman 2004). 
Several studies in the organizational psychology training literature suggest that training targeted specifically toward older workers is more effective for them, providing more extensive human capital development and, arguably, a stronger positive relationship with wages (Charness, Kelley, Bosman, \& Mottram 2001; Hedge, Borman, \& Lammlein 2006; Sterns \& Doverspike 1988; Sterns 1986). Based on this literature, we expect establishments that offer targeted training programs, whether in combination with involvement in standard training or as the only training practice for older workers, to have higher older worker retention rates (i.e., lower retirement rates).

Other practices may also encourage longer working lives, either individually or as part of a system of human resources (HR) practices. These include reduced performance requirements, mixed-age work teams, special equipment for older workers, and partial retirement allowing older workers to reduce their work hours before retiring. Because HR practices offered in bundles may have synergistic effects (B. E. Becker \& Gerhart 1996), we examine both direct and joint effects of training practices and other practices related to older workers. We expect that practices which allow older workers to perform work differently, such as reduced performance requirements and special equipment for older workers, and practices such as partial retirement that create schedule differences between older and younger workers, will be more likely to increase retention when combined with the offer of targeting training. Conversely, we expect the use of mixed aged teams to have a more positive effect on retention when older workers are included in offers of standard training also available to younger workers.

\section{Gender differences}

There are strong reasons to believe the relationship between training and retention may differ by gender among older German workers. On average, German women have substantially 
different labor market experiences than men, including less formal education and higher rates of part-time work (Brenke 2015). Occupational segregation by gender can also leave women with poorer economic stability upon retirement, which may affect their retirement decisions (Perkins 1993). Older men may have less to gain from training programs than older women if the returns to training in terms of productivity diminish with the amount of training received or if they are already at the top of their pay grades and thus would not choose to undertake further training because there would be little change in their pay. Alternatively, because of their longer labor force tenure, men may be more likely to select into industries that value industry and establishment specific human capital. If training programs for older workers complement prior investments then the gains from training may be greater and retention effects stronger for men. Finally, in Germany statutory age of eligibility for social security benefits has differed by gender. In cohorts born before 1946, women could retire with full old age social security benefits earlier than men, creating gender differences in the investment horizons for returns to training.

\section{A Possible Mechanism: Training and Wages}

Human capital theory predicts firm specific training enhances productivity and increases wages within the current firm relative to alternative employment opportunities, which enables the training firm to pay higher wages and provides incentives for both employers and employees to maintain the employment relationship (G. Becker 1962). In samples of workers of all ages, studies have found that on-the-job training is linked to higher employee productivity (Barrett \& O’Connell 2001; Bartel 1995; Conti 2005; Konings \& Vanormelingen 2009; Zwick 2006), slower depreciation of human capital (Groot \& Maassen van den Brink 2000; Neuman \& Weiss 1995), future employability (Crépon, Ferracci, \& Fougére 2007; Lechner, Miquel, \& Wunsch 2005) and wage growth (Bartel 1995; Dearden, Reed, \& Van Reenen 2006; Groot 1999). 
However older employees have fewer remaining years of work to reap the returns on their training investment (Ben-Porath 1967). So, even if training would increase productivity and wages, the effort required to participate in it may outweigh the benefits because the individual is close to retiring.

There are three reasons to expect training to increase retention especially for lower wage workers. First, if there are diminishing returns to training then those with less human capital may experience the greatest increase in productivity and wages when they participate in training, and those with less human capital (lower wage workers) are more likely to participate. Second, for institutional reasons even training that would boost productivity may be less likely to lead to a raise for high wage employees if they are already at the top of their paygrades. Third, even if training would lead to the same wage growth for low and high wage earners, high wage earners are likely to have greater non-labor income and have greater pension wealth assuming the same years of service under the German pension system. Thus, high wage earners would be more likely to respond to an increase in wages by choosing to retire than choosing to work longer. In addition to expecting differences in the effects of training on retention across the wage distribution, if wages are a mechanism through which training improves retention then the same training practices that promote retention should also be associated with greater wage growth.

\section{Methods}

\section{Sample}

This study uses matched data from the Linked Employer-Employee Data (LIAB) of the German Institute for Employment Research (IAB). The LIAB connects the German IAB Establishment Panel, an annual nationally representative survey of German establishments, with individual-level administrative data for the employees of participating establishments. The 
dataset includes all employees subject to social security and employed in one of the surveyed establishments on the reference date of June $30^{\text {th }}$. The IAB establishment panel began in 1993; however, not all questions are asked in each survey year. Questions about establishment training activities involving older workers were included in 2002, 2006, and 2008, so only those years are used in the present analysis. Over time, the sample of establishments has expanded to reflect changes in the German economy and remain representative of German establishments and establishments do not appear in every survey year both due to closure and survey non-response; thus our dataset is based on an unbalanced panel of individuals within establishments. ${ }^{2}$

Each individual may appear in the dataset up to three times (once in each year). The analysis sample includes all individuals between ages 50 and 65 . Workers younger than 50 are excluded because the questions about training on the establishment survey specifically refer to workers age 50 and older. Workers older than 65 are excluded because 65 is the normal pensionable age for German workers and very few work beyond this age. ${ }^{3}$ Our analysis sample contains 759,931 person-year observations for 50-65 year olds over the three study years, including 522,939 observations for men and 236,992 for women.

\section{Key Variables}

The dependent variable in the analysis is retirement from the establishment: "Retire." Retire is equal to 1 in the last year a worker appears in the LIAB data (using all years 20022008) and 0 in all earlier years (provided the establishment continues to appear), with missing

\footnotetext{
${ }^{2}$ A detailed discussion of sample selection and non-response can be found in (Heining, Scholz, \& Seth 2013). Full sample descriptive statistics for key variables are presented in Appendix Table A1.

${ }^{3}$ The number of person-year observations in our data at age 65 is approximately $7 \%$ of the number at age 60 . At age 66 , it falls to $0.8 \%$.
} 
values for years after the worker has left the data set. Because training information is only available in 2002, 2006 and 2008, we censor many retirements in our analysis dataset. For example, a worker who is employed in 2002 and retires in 2003 contributes only one observation to the analysis in 2002 with Retire equal to 0 . The 2003 retirement is censored because if the establishment did not offer training in 2002 but indicated training was offered by 2006 we cannot determine whether the individual's retirement preceded or followed the change in training practices because the training practice could have begun in 2003 and continued on through 2006 .

The key independent variables are binary indicators of the presence (1) or absence (0) of two training practices for older workers: Standard and Targeted. Standard indicates whether older workers are offered "advanced training activities" that are offered to other groups and thus delivered in a standard way and not specifically for older workers. Targeted indicates whether the establishment offers "special further training" specifically designed for older employees. It is important to note that we do not observe any information about the content of the training delivered using either method. Standard and targeted training programs may deliver general or firm specific skills. The distinction here is in the design and delivery of the training content. Standard reflects a "one size fits all" approach and Targeted reflects the availability of custom programs designed for older workers.

An additional important covariate, Participation, provides a measure of training participation across all establishment employees. Participation is reported in the establishment survey as either the number of individuals participating in training over the year or the number of instances of training. In the latter case, an employee participating in two training programs would be counted twice. Establishments decide how to report their training participation. We normalized this variable by dividing it by the total number of employees in the establishment 
multiplied by 100 . We control for their choice of reporting using Reporting, a binary indicator equal to 1 for establishments that report training participation as total incidences. Thus, regressions that include Participation also include Reporting as well as an interaction between the two variables. Participation was not included in the 2002 or 2006 establishment survey modules so we match data from the 2001 and 2003 surveys to these years. This decision is supported by descriptive statistics that show Participation was relatively stable over time within establishments; Participation had an intra-class correlation coefficient of 0.943 , indicating that less than $6 \%$ of the observed variance in Participation is due to within-establishment changes over time.

\section{Empirical Specifications: Relationship between Training and Retention}

Although the Participation variable indicates the extent to which workers in the establishment have participated in training, it does not tell us which workers participated. This means what we are estimating are the "intention-to-treat" (ITT) effects of an establishment offering Standard and Targeted training, rather than the specific effects of an individual receiving trainings (although moderated by our inclusion of Participation). One issue is that establishment training practices are not randomly assigned, introducing potential selection bias into the estimates. We minimize the likely bias by including observable time varying attributes, and establishment fixed-effects, which will account for all potential time-invariant confounders.

Specifically, we specify a discrete time hazard model where Retire is a function of our training practices Standard and Targeted, Participation, individual characteristics, establishment attributes, general time effects, and establishment fixed-effects according to: 


$$
\begin{aligned}
\text { Retire }_{i j t}=\beta_{0} & +\beta_{1} \text { Standard }_{j t}+\beta_{2} \text { Targeted }_{j t}+\beta_{3} \text { Participation }_{j t} \\
& +\beta_{4} \text { Reporting }+\beta_{5} P * R+X_{i j t} \theta+Z_{j t} \delta+\lambda_{j}+\varepsilon_{i j t}
\end{aligned}
$$

In [1], the subscripts $i, j$, and $t$ index individuals, establishments and survey year; $P^{*} R$ is the interaction between Participation and Reporting; $X$ is a vector of individual covariates and $Z$ are time varying establishment covariates, both defined below; $\lambda_{t}$ is establishment fixed effects. All estimated standard errors are heteroscedasticity robust and clustered at the establishment level. We estimate Equation [1] separately for men and women to flexibly model likely gender differences in the relationship between our key variables, other covariates, and retirement behavior.

In [1], $\beta_{1}$ and $\beta_{2}$ estimate the effects of offering each type of training on retirement hazard rates, which are defined as the probability that an individual retires in year $t$ provided that they have not retired by $t-1$. If the offer of training promotes retention of older workers then its coefficient should be negative. $\beta_{3}$ estimates the marginal change in retirement likelihood resulting from a one percentage point change in the training participation measure for establishments that report Participation as the number of individuals $($ Reporting $=0)$, and $\beta_{3}+$ $\beta_{5}$ provides the marginal effect for establishments that report number of training incidences $($ Reporting $=1) . \beta_{4}$ reflects any differences in retirement behavior when establishments change to reporting training as incidences instead of individuals. Fixed differences between establishments due to different reporting styles are captured by $\lambda_{\mathrm{j}}$.

$X$ includes individual establishment tenure, daily wage rate, educational attainment, and whether the individual works part-time. Among full-time employees, we control for blue-collar versus white-collar occupations. All regressions control for individual age using a full set of age dummy variables to capture discontinuities in retirement behavior due to norms and pension 
incentives. $Z$ includes time varying measures of establishment annual revenue, total employment, and average employee wage. We also include a subjective measure of establishment profitability, rated on a five-point scale from "unsatisfactory" to "very good," to better capture financial performance.

Including establishment fixed effects helps to rule out the possibility that establishments adopting training practices for older workers are generally better places to work and so would have higher retention rates, even without offering training. However, it does not eliminate the possibility that establishments adopting training practices also implemented other practices that are aimed at older workers that could affect retention. Synergistic bundles of practices with similar goals are common as part of high-performance work systems (Appelbaum, Bailey, Berg, \& Kallleberg 2000), and it may be the entire bundle of practices, rather than just training practices, that lead to higher retention. To address this possibility, we add a set of indicator variables for other older worker practices to Equation [1] including: the use of special equipment (Special Equipment) or lower performance targets (Lower Performance) for older workers, offers of partial retirement (Partial Retirement), use of mixed age teams (Mixed Age), and any other practices for older workers (Other). We also interact these variables with Standard and Targeted to determine whether the effects of training may differ when used in conjunction with other older worker practices.

To examine wages as a potential mechanism through which training practices may affect retention, we first expand Equation [1] to include interactions between individual wages and each training practice. This allows the effects of offering standard and targeted training to differ for persons earning lower versus higher wages, relative to the entire sample average. We summarize the results of this model by estimating marginal effects of each practice at the $25^{\text {th }}$, 
$50^{\text {th }}$ and $75^{\text {th }}$ percentiles of the labor market wage distribution defined separately for men and for women and with the inclusion of younger workers' wages.

However, an individual's position in the labor market distribution is not necessarily the same as position within the establishment earning distribution. As explained, one reason to expect a weaker relationship between training and retention among older workers is older workers are more likely to be near the top of their pay grades within the establishment. Although we do not have information on actual pay grades, our data contains individual wages for all workers (young and old) within the establishment in each year and from this information we construct establishment specific wage quintiles and define a categorical variable, $E W Q$, which is equal to the establishment wage quintile each older worker in our analysis sample falls within. We again expand Equation [1] to include interactions between each training practice and $E W Q$, which allows us to examine whether the relationships between training practices and retention differ by position in the establishment wage distribution. If relationships between training and retention are weaker because older workers are near the tops of their pay grades, we would expect to see point estimates that are closer to zero or even positive for individuals in the highest establishment wage quintiles and point estimates that are negative for individuals in the lowest quintiles.

If wages are a mechanism through which training practices influence retention of older workers, then there should be a direct relationship between establishment training practices and wages. To test for this relationship, we estimate the following regression equations:

$$
\ln \left(\text { wage }_{i t}\right)=\beta_{0}+\beta_{1} \text { Standard }_{j t}+\beta_{2} \text { Targeted }_{j t}+\beta_{3} \text { Participation }_{j t}
$$




$$
\begin{aligned}
& +\beta_{4} \text { Report }_{j t}+\beta_{5} P * R_{j t}+X_{i j t}^{-} \theta+Z_{j t} \delta+\varepsilon_{i j t} \\
& \frac{\text { wage }_{i j t+1}-\text { wage }_{i j t}}{\text { wage }_{i j t}}=\beta_{0}+\beta_{1} \text { Standard }_{j t}+\beta_{2} \text { Targeted }_{j t}+\beta_{3} \text { Participation }_{j t} \\
& +\beta_{4} \text { Report }_{j t}+\beta_{5} P * R_{j t}+X_{i j t} \theta+Z_{j t} \delta+\varepsilon_{i j t} \\
& E W Q_{-} U p=\beta_{0}+\beta_{1} \text { Standard }_{j t}+\beta_{2} \text { Targeted }_{j t}+\beta_{3} \text { Participation }_{j t} \\
& +\beta_{4} \text { Report }_{j t}+\beta_{5} P * R_{j t}+X_{i j t} \theta+Z_{j t} \delta+\varepsilon_{i j t}
\end{aligned}
$$

Equation [2] is a semi-log wage equation. Because Standard and Targeted are dummy variables, we compute the percentage change in individual wages associated with the introduction of each policy as: $100\left[\exp \left(\widehat{\beta_{1}}\right)-1\right]$ and $100\left[\exp \left(\widehat{\beta_{2}}\right)-1\right]$, respectively (Halvorsen \& Palmquist 1980). Because individual wages in year $t$ are the dependent variables in this model, the vector of individual control variables $X$ does not include individual wages in this equation and is denoted as $X_{i j t}^{-}$. All other variables and parameters are the same as in Equation [1]. If training does lead to higher wages for older workers, we expect to find positive estimates for both $\beta_{1}$ and $\beta_{2}$ in Equation [2].

In Equation [3] we specify a wage growth equation to attempt to answer the question: Is individual wage growth greater among older workers when their establishments offer either type of training? The dependent variable is now the percentage change in individual wages from the current survey year, $t$, to the next survey year, $t+1$. Here individual wages are included as a control variable in the vector $X_{i j t}$, so $\beta_{1}$ and $\beta_{2}$ estimate the percentage point difference in wage growth when establishments offer each training relative to when they do not, holding wage levels constant at the market average for survey year $t$. 
If establishments that offer training simply pay better all the time and pay larger raises over time and do not do so because the training has enhanced the productivity of their workers, it is possible any relationships between training and wages or wage growth we find after estimating Equations [2] and [3] will be spurious. Establishment fixed effects will not control for time varying differences in wage levels and growth across establishments; that is, we cannot rule out the possibility that individuals in establishments with these training practices have different wage trajectories. Instead, we use the $E W Q$ variable, which measures individual's positions within their establishment's wage distribution in each year, to create the binary variable $E W Q U p$, which is equal to 1 if the individual moves up one or more quintiles within the establishment wage distribution from year $t$ to year $t+1$. Because $E W Q$ is defined on the establishment wage distribution observed in each survey year $t, E W Q U p$ captures whether individual wages are increasing relative to movements in the overall distribution of establishment wages. Because we do not observe who participates in the offered training programs and who does not, we cannot directly test whether wages, growth or movements up the establishment wage distribution differ among training participants and non-participants.

\section{Results}

\section{Differences in establishment and individual characteristics by training activities}

To understand the context in which training activities for older worker are occurring, we review differences in observed values of establishment characteristics by establishment training practices Standard and Targeted. Table 1 contains means for selected establishment covariates by training practice. Specifically, we average covariates across survey years for each establishment and then take the grand mean of those averages for establishments that 
consistently offer neither practice, both practices, and one but not the other in all survey years. There are 770 additional establishments that change training practices during the study period.

Relative to establishments with neither practice, establishments that consistently offer either or both of the training practices have higher training participation in the establishment as a whole, employ fewer unskilled workers and more workers overall, and are more likely to offer other practices for older workers. Very few establishments offer targeted training without standard training but those that do appear to be similar to establishments that offer only standard training, except average wages are lower in establishments offering only targeted training. There are some significant differences in the number of retirements per year by training practice. In general establishments that offer training of either type have more retirements, but they also have more employees overall. The ratios of retirement turnover to employment are very similar for each establishment group. ${ }^{4}$

In total, because of the higher wages in establishments that offer standard training or both practices and the greater prevalence of other older workers practices, there is evidence that training establishments may be better places to work overall than establishments that do not train, and this observation underscores the importance of controlling for these observables and using fixed effects estimation to address unobserved time constant heterogeneity in establishments. Also, the differences in average wage levels suggest that correlations between individual wages and training practices may be spurious, so it is important to examine individual wages relative to the establishment wage distribution and exploit the longitudinal data available to examine movements within the establishment wage distribution.

\footnotetext{
${ }^{4}$ The ratios are: 0.007 for establishments offering standard training only, 0.006 for establishments offering targeted training only, 0.008 for establishments offering both, and 0.006 for establishments offering neither.
} 


\section{Relationships between training practices and retirement}

In Table 2, we test the relationship between offers of training and retirement. Models 1 and 2 contain our baseline estimates of the relationship between establishment training practices and retirement for men and women, respectively ${ }^{5}$. The analysis suggests there is no relationship between the offer of either standard or targeted of training and retirement among older men, and no relationship between overall training participation in the establishment and retirement for either men or women. We find the probability of retirement is 1.61 percentage points lower for women when establishments offer targeted training than when they do not $(p=0.07)$. When we control for establishment use of other practices for older workers (Columns 3 and 4, Table 2) there are no important changes in the estimated effects of training practices or many other covariate coefficients. The only statistically significant relationship between retention and other practices for older workers is for partial retirement among men; men employed in establishments that offer partial retirement have a 1.38 percentage point lower likelihood of retirement $(\mathrm{p}=$ $0.03)$.

Contrary to our expectations, findings do not differ if we expand the model to include all two-way interactions between training practices and other practices for older workers. For example, for women, we find the offer of standard training was associated with a 3 percentage point increase in retirement likelihood when used alone, but the coefficient estimate for the interaction between offer of standard training and offer of partial retirement was -3 percentage points. So the total effect of offering standard training when partial retirement is also offered is effectively zero (See Appendix Table A3). In general, there is no consistent pattern that supports the joint effects of training and other practices on retirement likelihood.

\footnotetext{
${ }^{5}$ Table 2 reports results for key variables. Full regression results are reported in Appendix Table A2.
} 
Above, we argue that training may promote longer working lives through increased older worker wages. Interactions between wages and training practices suggest there are systematic differences in the effects of targeted training between low and high wage women (Figure 1). Women whose wages are at the $20^{\text {th }}$ percentile of the market wage distribution for women have retirement likelihoods that are $2.64(\mathrm{p}=0.01)$ percentage points lower when their establishment offers targeted training. At the $40^{\text {th }}$ wage percentile the estimated effect is 2.11 percentage points lower $(p=0.03)$, at the $60^{\text {th }}$ it falls to 1.67 percentage points lower $(p=0.07)$, and for women at the $80^{\text {th }}$ percentile the estimated reduction is only 1.09 percentage points and is not statistically significantly different from zero $(p=0.23)$. Although the estimate at the $20^{\text {th }}$ percentile is statistically significantly different from zero, it is not different from the estimate at the $80^{\text {th }}(\mathrm{p}=$ 0.27) and therefore we have suggestive but not definitive evidence of strong effects of targeted training on retention for lower wage women. For involvement in standard training, there appears to be no effect on retention for women at any wage level. A positive trend also exists across the wage distribution for both standard and targeted training among men, but no estimates are statistically significantly different from zero and the point estimates for lower wage men are far smaller (in absolute value) than for lower wage women (Figure 2).

When we measure individual wages by quintile within the establishment wage distribution and interact the quintile dummies with each training practice, the differences in the effects of targeted training between the lowest earners and others are even larger. For women, we find a 3.29 percentage point reduction when establishments offer targeted training, which is also statistically significantly different from zero $(\mathrm{p}=0.00)$ and from the estimate for top quintile earners $(p=0.08)$ (Figure 3). Interestingly, we also find that when establishments offer standard training, women in the $4^{\text {th }}$ and $5^{\text {th }}$ wage quintiles have retirement likelihoods that are $0.9(\mathrm{p}=$ 
$0.06)$ and $1.5(\mathrm{p}=0.00)$ percentage points higher than when standard training is not offered. We find a 2.05 percentage point reduction in retirement likelihoods for men in the lowest wage quintile when establishments offer standard training, which is both statistically significantly different from zero $(\mathrm{p}=0.00)$ and from the 0.48 percentage point increase in retirement probability estimated for men in the top quintile (0.00) (Figure 4). In total, these estimates indicate training matters most for men and women who earn the least, and while offering standard training significantly improves retention for low wage men and targeted training does not, the opposite is true for low wage women.

\section{Why does training improve retention among low wage earners?}

To understand why the offer of training appears to improve retention most among lower earners, we investigate the relationship between training practices and wages. Descriptive statistics in Table 1 suggest establishments that have training practices for older workers pay higher wages. To examine this apparent relationship more rigorously, we regress log wages on training practices and individual and establishment characteristics with and without establishment fixed effects (Table 3). If the correlation between wages and training is simply because these establishments always pay more overall and not due to the training per se (i.e., if it is spurious), then any positive relationship in the OLS regression should not persist when establishment fixed effects are added. This is precisely what we find for women. Women's wages are $2.3 \%$ higher in establishments that offer standard training to older workers relative to those that do not, and also $2.3 \%$ higher in establishments that offer targeted training to older workers according to the OLS regressions (Column 1, Panel B). However, the fixed effects estimates suggest this relationship was due to fixed establishment characteristics and not the practices themselves because all point estimates for women in the fixed effects regressions are 
not statistically significant and imply a percentage difference in wages close to zero when each practice is offered relative to when it is not (Column 2). For men, we find statistically significant positive relationship $(p=0.03)$ between the offer of standard training and wages in the fixed effects model, but the point estimate indicates wages are only $0.4 \%$ higher when establishments offer standard training (Column 2, Panel A).

Although training practices may not be associated with economically important differences in wage levels, they could generate greater individual wage growth. As explained previously, human capital theory predicts training will lead to longer employment relationships because it boosts both worker productivity and wages. If wages are in fact the mechanism for the relationship between training and retention, we should see greater wage growth associated with the practices that promote retention: offer of standard training among men and targeted training among women.

To test this relationship, we first estimate Equation [3] where the dependent variable is individual wage growth across survey years. Our sample size is much smaller in these models due primarily to the fact that many people in our sample retire during the 2 and 4 year gaps between surveys, and also because of establishment attrition across survey years (due both to closures and non-participation in the survey). These regressions suggest wage growth is 3.08 percentage points higher for women $(\mathrm{p}=0.06)$ in establishments that offer targeted training and 3.48 percentage points lower for men $(\mathrm{p}=0.06)$. Also, for men the offer of standard training is associated with wage growth that is 2 percentage points higher than in establishments without it $(\mathrm{p}=0.10)($ Column 3).

Although the relationships between wage growth and training practices do exhibit expected patterns given that we find the offer of standard training was associated with greater 
retention among low wage men and targeted training was associated with greater retention among low wage women, these estimates could simply reflect higher overall wage growth throughout establishments that have these practices. To isolate wage growth among older workers from potential differences in establishment payroll trends, we estimate Equation [4] with a "wage mobility indicator", $E W Q_{-} U p$, as the dependent variable to indicate whether the older worker is in a higher wage quintile within the establishment wage distribution in the next survey year.

For women we find targeted training is associated with a two percentage point higher probability of being in a higher wage quintile in the next survey year $(\mathrm{p}=0.06)$, which is consistent with our wage growth findings and suggests older women in establishments with targeted training are moving up the establishment wage distribution (Column 4, Panel B). We do not find the same for men. Instead, men in establishments that involve older workers in standard training are 2.4 percentage points less likely to be in a higher wage quintile by the next survey ( $\mathrm{p}$ $=0.08)$ (Column 4, Panel A). Although the point estimate for targeted training for men is large relative to other estimates and is positive, it is not statistically significant $(p=0.25)$. In total, there is no evidence that training of either type is associated with greater wage mobility among men.

\section{Reverse causality: Does higher retention lead to adoption of training practices?}

The foregoing analysis relies upon establishment fixed effects and an extensive list of time varying covariates to address non-random assignment of training practices across establishments suggested in the descriptive statistics in Table 1. Yet, establishments may be adopting training practices in response to past trends in retention that would not be captured by establishment fixed effects. For example, establishments may only offer training to older workers 
because the establishment has high retention rates and they know employment relationships will be long enough to recoup the training investment. This potential reverse causality may lead us to infer the wrong explanations from our main results.

To empirically investigate this possibility, we run two regressions- - one for each training practice - with training practice variables Standard and Target in survey year 2006 as the dependent variables and regress them on establishment and worker characteristics in 2002. Results are reported in Appendix Table A4. We find two significant associations between 2002 retirement behavior and establishment offer of training practices. First, men who retired in 2002 were 2 percentage points less likely to work in establishments that offer standard training. Although the effect size is small, the sign suggests establishments that started offering standard training in 2006 may have already had higher retention rates among men to begin with, which means the relationships we found between standard training and retention among men may not be attributable to a causal effect of training on retention. Second, we find women who retired in 2002 were 1 percentage point more likely to work for establishments that offer targeted training and we find no association between men's retirement in 2002 and the offer of targeted training practices in 2006. This suggests establishments that adopted targeted training programs for older workers had worse retention rates among women to begin with and no difference in retention among men. So our finding that women are less likely to retire when working in establishments offering targeted training is less likely to be due to reverse causality and may actually slightly underestimate the true relationship between offer of targeted training and retention if the establishment fixed effects do not fully capture pre-existing differences in retention rates. 


\section{Discussion}

Our results suggest that the relationship between establishment training practices and the retention of older workers is complex. On average, establishment training offerings are unassociated with longer working lives for men, but older women employees had retirement rates that were 2 percentage points lower when targeted training was offered relative to when it was not. Also, for both men and women in the lowest quintile of their establishment's wage distribution we find training practices are associated with lower retirement likelihoods, but the delivery of training matters. Low wage women are less likely to retire if offered training targeted to meet the needs of older workers but the offer of involvement in standard establishment training programs does not change women's retirement behavior. The opposite is true for men.

We also find evidence that wage increases may be a mechanism through which establishment training offerings are related to retention of older female employees. For women, targeted training offerings were associated with wage growth across survey years and a higher likelihood of moving up the establishment wage distribution, but offer of standard training was associated with neither. These findings are consistent with the relationships we find between training practices and retention of female employees: women were less likely to retire when offered targeted training but standard training had no relationship with retirement behavior.

The evidence for men is less consistent. Although we find standard training is associated with lower retirement probabilities among low wage men, and we find men's wage growth is greater when standard training is offered, we find no evidence of wage increases relative to the establishment distribution and some evidence that older men's wages may fall relative to the establishment distribution when standard training is offered. So, we cannot rule out the 
possibility that men's wage trajectories are simply steeper in establishments that offer standard training to older workers and no causal link exists.

These results raise several questions. First, why might wages be an important mechanism for women, but not for men? Second, why do we see relationships for targeted training and retirement likelihood among women and not standard training? Gender differences in lifecycle labor supply and human capital profiles offer potential answers for both of these questions. Evidence from previous research suggests that women have substantially different lifecycle labor supply patterns than men, especially in Germany (Ollier-Malaterre 2014). Women in the cohorts we study are far more likely to work part-time and to exit the labor force during prime working age years and this impacts their acquisition of human capital and earnings (Mincer \& Polachek 1974). Rates of re-entry into the workforce are high among German women aged 40 to 60 . For example, at ages 30 to 34 women born in 1946 to 1950 had a labor force participation rate of $57.9 \%$ and it rose to $65.6 \%$ by ages 40 to 44 and was $71.9 \%$ at ages 50 to 54 (OECD.Stat 2015). Women re-entering the workforce may have substantially different needs for training than other workers. So, an establishment that offers targeted training to fill skills gaps or address skill obsolescence may be able to increase women's productivity, and in turn their wages. Because men tend to have fewer career interruptions, targeted training may not have any impact on their wages or retirement behavior. Unfortunately without more information about the actual content of training and a thorough analysis of employment histories, we are unable to do more than postulate this explanation, but given our findings and the importance of understanding women's lifecycle labor supply this seems an important area for future research.

Involvement in standard training activities may not move older men up the earning distribution because they are more likely to be at the top of their pay grades and therefore would 
not see a meaningful financial return on training. Lacking information on pay grades, we have used position within the establishment earnings distribution as a proxy. Future research using data with paygrade information or in restricted samples of large establishments where pay distributions could be computed within occupations may offer a more rigorous test.

Finally, even if the financial returns to training are the same for men and women, women are more likely than men to experience financial insecurity upon reaching retirement age (Brenke 2015). So, women may be more likely to respond to an increase in wages by postponing retirement whereas men may be more likely to respond by retiring earlier. ${ }^{6}$ The LIAB does not contain direct measures of pension wealth or private savings to test this possibility.

These findings have important implications for policy. The National Council on Aging reports older women in the U.S. receive $\$ 4,000$ less than older men in annual Social Security benefits due to differences in work histories and wages (National Council on Aging 2015). A recent Dēmos.org and Institute on Assets \& Social Policy (IASP) brief indicates the proportion of single women over age 65 who are economically insecure rose by one-third between 2004 and 2008 (Meschede, Cronin, Sullivan, \& Shapiro 2011). Our results suggest offering targeted training may both improve women's earnings while working, and encourage longer working lives.

We caution that if our findings for women are the result of training helping women who are re-entering the workforce to make up for human capital decay and skill obsolescence then these practices may be less effective in organizations with high rates of labor force participation among prime-aged women and for younger cohorts of women who have higher rates of labor force attachment. This would be an interesting area for future research. A study that compares

\footnotetext{
${ }^{6}$ That is, the substitution effect associated with a wage increase may be more likely to dominate the income effect for women than men.
} 
organizations with different female age profiles, gender composition, and training practices could be very helpful in further clarifying the relationship between training practices and the retention of older workers.

\section{Limitations and Conclusion}

The study has a few limitations that should caution interpretation of the results. First, the results of the wage growth and mobility analyses should be confirmed in panel data with lower attrition rates. Second, we can only estimate intent to train effects as opposed to average treatment effects as the dataset does not include individual training participation. Finally, in some specifications the reporting style of Participation is statistically significant, which makes the results more difficult to interpret and suggests reporting style may be associated with other firm characteristics related to employees' retirement decision. This may mean there are relationships between offer of training to older workers and overall establishment training participation that are missed in this analysis.

When establishments offer targeted training for older workers, women — and especially lower wage women - are less likely to retire. This may be because offers of targeted training are associated with both greater wage growth and movement into higher wage quintiles within the establishment. Although we find some evidence of lower retirement probabilities for men in establishments that involve older workers in standard training, we also find retirement likelihoods among men may already be lower in these establishments before practices are adopted. Also, although standard training is associated with higher wage growth for men our findings suggest this may be because these establishments have higher wage growth overall rather than among older men in particular. 


\section{References}

Appelbaum, E., Bailey, T., Berg, P., \& Kallleberg, A. L. (2000). Manufacturing Advantage: Why High Performance Work Systems Pay Off. Ithaca, NY: ILR Press.

Armstrong-Stassen, M., \& Ursel, N. D. (2009). Perceived organizational support, career satisfaction, and the retention of older workers. Journal of Occupational and Organizational Psychology, 82(1), 201-220. doi:10.1348/096317908X288838

Barrett, A., \& O'Connell, P. J. P. (2001). Does training generally work? The returns to incompany training. Industrial and Labor Relations Review, 54(3), 647.

Bartel, A. P. (1995). Training, Wage Growth, and Job Performance: Evidence from a Company Database. Journal of Labor Economics, 13(3), 401. doi:10.1086/298380

Becker, B. E., \& Gerhart, B. (1996). The impact of human resource management on organizational performance: Progress and prospects. Academy of Management Journal, 39(4), 779-801.

Becker, G. (1962). Investment in human capital: A theoretical analysis. The Journal of Political Economy, 70(5), 9-49.

Beier, M. E. (2012). Age and Learning in Organizations. In G. P. Hodgkinson \& J. K. Ford (Eds.), International Review of Industrial and Organizational Psychology, Volume 23 (Vol. 23, pp. 83-105). John Wiley \& Sons Ltd.

Ben-Porath, Y. (1967). The production of human capital and the life cycle of earnings. The Journal of Political Economy, 75(4), 352-365.

Blau, J. (2011). Aging Germany must keep older workers healthy and happy. Deutsche Welle. Retrieved from http://dw.de/p/106ay

Boockmann, B., Fries, J., \& Goebel, C. (2012). Specific Measures for Older Employees and Late Career Employment (No. 12-059). Retrieved from http://ftp.zew.de/pub/zewdocs/dp/dp12059.pdf

Börsch-supan, A. H., \& Wilke, C. B. (2003). The German Public Pension System: How it Was, How it Will Be (No. 34-2003). Mannheim.

Brenke, K. (2015). Growing Importance of Women in the German Labor Market. DIW Economic Bulletin, (5), 51-62.

Buss, K.-P., \& Kuhlmann, M. (2013). Akteure und Akteurskonstellationen alter(n)sgerechter Arbeitspolitik. WSI - Mitteilungen, (5), 350-359. 
Callahan, J., Kiker, D., \& Cross, T. (2003). Does method matter? A meta-analysis of the effects of training method on older learner training performance. Journal of Management, 29(5), 663-680. doi:10.1016/S0149-2063

Cappelli, P. (2014). Skill Gaps, Skill Shortages and Skill Mismatches: Evidence for the US (Working Paper No. 20382). National Bureau of Economic Research.

Charness, N., Kelley, C. L., Bosman, E. a., \& Mottram, M. (2001). Word-processing training and retraining: Effects of adult age, experience, and interface. Psychology and Aging, 16(1), 110-127. doi:10.1037//0882-7974.16.1.110

Conti, G. (2005). Training, productivity and wages in Italy. Labour Economics, 12(4), 557-576. doi:10.1016/j.labeco.2005.05.007

Crépon, B., Ferracci, M., \& Fougére, D. (2007). Training the Unemployed in France: How Does it Affect Unemployment Duration and Recurrence? Annales d'Economie et de Statistique. Bonn, Germany.

Danson, M. (2007). Older workers in the labour market: the demographic context. In W. Loretto, S. Vickerstaff, \& P. J. White (Eds.), The Future for Older Workers: New Perspectives. Bristol, UK: The Policy Press.

Dearden, L., Reed, H., \& Van Reenen, J. (2006). The Impact of Training on Productivity and Wages: Evidence from British Panel Data. Oxford Bulletin of Economics and Statistics, 68(4), 397-421. doi:10.1111/j.1468-0084.2006.00170.x

Dietz, M., \& Walwei, U. (2011). Germany--No Country for Old Workers? Zeitschrift Fuer ArbeitsmarktForschung, 44(4), 363-376.

Elliott, L., \& Kollewe, J. (2011, March). Germany faces up to problem of ageing workforce. The Guardian.

Eurostat. (2011). EU27 population is expected to peak by around 2040.

Ford, J. K., \& Oswald, F. (2003). Understanding the dynamic learner: Linking personality traits, learning situations, and individual behavior. In M. R. Barrick \& A. M. Ryan (Eds.), Personality and Work: Reconsidering the role of personality in organizations. John Wiley \& Sons Ltd.

Fouarge, D., \& Schils, T. (2009). The effect of early retirement incentives on the training participation of older workers. Labour, 23, 85-109.

Groot, W. (1999). Productivity effects of enterprise-related training. Applied Economics Letters, 6(6), 369-371. doi:10.1080/135048599353104 
Groot, W., \& Maassen van den Brink, H. (2000). Overeducation in the labor market : a metaanalysis. Economics of Education Review, 19(2), 149-158. doi:10.1016/S02727757(99)00057-6

Halvorsen, R., \& Palmquist, R. (1980). The interpretation of dummy variables in semilogarithmic equations. American Economic Review, 70(3), 474-75.

Hausknecht, J. P., \& Trevor, C. O. (2010). Collective Turnover at the Group, Unit, and Organizational Levels: Evidence, Issues, and Implications. Journal of Management, 37(1), 352-388. doi:10.1177/0149206310383910

Heavey, A. L., Holwerda, J. a, \& Hausknecht, J. P. (2013). Causes and consequences of collective turnover: a meta-analytic review. The Journal of Applied Psychology, 98(3), 41253. doi:10.1037/a0032380

Hedge, J. W., Borman, W. C., \& Lammlein, S. E. (2006). Age Stereotyping and age discrimination. In J. W. Hedge, W. C. Borman, \& S. E. Lammlein (Eds.), The Aging Workforce: Realities, Myths, and Implications for Organizations (pp. 27-48). Washington, DC: American Psychological Association.

Heining, J., Scholz, T., \& Seth, S. (2013). Linked-Employer-Employee Data from the IAB: LIAB Cross-Sectional Model 2 1993-2010 (LIAB QM2 9310). Bundesagentur fur Arbeit.

Herrbach, O. O., Mignonac, K., Vandenberghe, C., \& Negrini, A. (2009). Perceived HRM Practices, organizational commitment, and voluntary early retirement among late-career managers. Human Resource Management, 48(6), 895-915. doi:10.1002/hrm.20321

Kanfer, R., \& Ackerman, P. P. L. (2004). Aging, adult development, and work motivation. Academy of Management Review, 29(3), 440-458.

Konings, J., \& Vanormelingen, S. (2009). The impact of training on productivity and wages: firm level evidence. LICOS - Discussion Paper Series DP244/2009. London. doi:10.1162/REST_a_00460

Kristensen, N. (2012). Training and retirement (No. 6301). Retrieved from http://nbnresolving.de/urn:nbn:de:101:1-201204239412

Lechner, M., Miquel, R., \& Wunsch, C. (2005). The Curse and Blessing of Training the Unemployed in a Changing Economy: The Case of East Germany After Unification.

Meschede, T., Cronin, M., Sullivan, L., \& Shapiro, T. (2011, October). Rising Economic Insecurity Among Senior Single Women. Demos.org and Institute on Assets \& Social Policy.

Mincer, J., \& Polachek, S. (1974). Family Investments in Human Capital: Earnings of Women. The Journal of Political Economy, S76-S108. 
Montizaan, R., Cörvers, F., \& De Grip, A. (2010). The effects of pension rights and retirement age on training participation: Evidence from a natural experiment. Labour Economics, 17(1), 240-247. doi:10.1016/j.labeco.2009.10.004

National Council on Aging. (2015). Economic Security for Seniors Facts.

Neuman, S., \& Weiss, A. (1995). On the effects of schooling vintage on experience-earnings profiles: Theory and evidence. European Economic Review, 39, 943-955. doi:10.1016/0014-2921(94)00019-V

OECD.Stat. (2015). Dataset: LFS - Sex and Age Indicators (Dataset Level Metadata). Retrieved from OECD.Stat. 2015. "Dataset: LFS - Sex and Age Indicators (Dataset Level Metadata)." http://www.oecd.org/els/employmentpoliciesanddata/LFSNOTES_SOURCES.pdf.

Ollier-Malaterre, A. (2014). Cross-National Work-Family Research: A Review at the Individual Level. In T. D. Allen \& L. T. Eby (Eds.), Oxford Handbook of Work and Family (pp. 1-38). Oxford: Oxford University Press.

Osterman, P., \& Weaver, A. (2014). Why claims of skills shortages in manufacturing are overblown. Washington, DC: Economic Policy Institute.

Paullin, C., \& Whetzel, D. (2012). Retention strategies and older workers. In J. W. Hedge \& W. C. Borman (Eds.), The Oxford Handbook of Work and Aging. Oxford: Oxford University Press.

Perkins, K. (1993). Working-Class Women and Retirement. Journal of Gerontological Social Work, 20, 129-148.

Picchio, M., \& van Ours, J. C. (2012). Retaining through training: Even for older workers. Economics of Education Review, 32(C), 29-48.

Schlick, C. M., Frieling, E., \& Wegge, J. (Eds.). (2013). Age-Differentiated Work Systems. Berlin: Springer Verlag.

Sterns, H. L. (1986). Training and Retraining Adult and Older Adult Workers. In J. E. Birren, P. K. Robinson, \& J. E. Livingston (Eds.), Age, Health, and Employment. (pp. 93-113). Englewood Cliffs, NJ: Prentice-Hall.

Sterns, H. L., \& Doverspike, D. (1988). Training and developing the older worker: implications for human resource management. In H. Dennis (Ed.), Fourteen Steps in Managing an Aging Workforce. Lexington, MA: Lexington Books.

Wanger, S., Weber, B., \& Fuchs, J. (2013). Kann ein Anstieg der Arbeitszeit den Rückgang des Arbeitskräfteangebots kompensieren? In M. Göke \& T. Heupel (Eds.), Wirtschaftliche Implikationen des demografischen Wandels. Herausforderungen und Lösungsansätze (FOM., pp. 335-348). Wiesbaden: Springer Verlag. 
Zwick, T. (2006). The Impact of Training Intensity on Establishment Productivity. Industrial Relations, 45(1), 26-46. doi:10.1111/j.1468-232X.2006.00412.x 
Table 1. Establishment Characteristics by Training Practice Offered ${ }^{\mathrm{a}}$

\begin{tabular}{lcccc}
\hline Practice: & $\begin{array}{c}\text { Standard } \\
\text { only }\end{array}$ & $\begin{array}{c}\text { Targeted } \\
\text { only }\end{array}$ & $\begin{array}{c}\text { Standard } \\
\text { and } \\
\text { targeted }\end{array}$ & $\begin{array}{c}\text { Neither } \\
\text { practice }\end{array}$ \\
\hline Overall Training Participation & $35.645^{* * *}$ & $35.43^{* * *}$ & $39.446^{* * *}$ & 22.951 \\
& $(26.812)$ & $(24.589)$ & $(30.038)$ & $(24.758)$ \\
Average Daily Wage & $84.527^{* * *}$ & 75.814 & $88.697^{* * *}$ & 75.174 \\
& $(24.994)$ & $(26.213)$ & $(28.292)$ & $(24.978)$ \\
Share Unskilled Workers & $0.145^{* * *}$ & 0.141 & $0.111^{* *}$ & 0.185 \\
& $(0.203)$ & $(0.219)$ & $(0.159)$ & $(0.249)$ \\
Perceived Profitability & $3.387^{* * *}$ & $3.161^{* *}$ & 3.53 & 3.547 \\
& $(1.601)$ & $(1.787)$ & $(1.559)$ & $(1.412)$ \\
Revenue, Billions $€$ & $4.24 \mathrm{e}^{8 * *}$ & $1.42^{*} \mathrm{e}^{8 * * *}$ & $2.16^{*} \mathrm{e}^{8}$ & $2.18^{*} \mathrm{e}^{8}$ \\
& $\left(3.87^{*} \mathrm{e}^{9}\right)$ & $\left(4.30^{*} \mathrm{e}^{8}\right)$ & $\left(4.97 * \mathrm{e}^{8}\right)$ & $\left(7.33^{*} \mathrm{e}^{9}\right)$ \\
Employment & $421.857^{* * *}$ & $440.27^{* * *}$ & $565.363 * * *$ & 185.6 \\
& $(1340.906)$ & $(747.474)$ & $(825.79)$ & $(524.47)$ \\
Partial Retirement Policy & $0.668^{* * *}$ & $0.518^{* *}$ & $0.653^{* * *}$ & 0.362 \\
& $(0.466)$ & $(0.504)$ & $(0.476)$ & $(0.473)$ \\
Have Special Equipment for Older & $0.15^{* * *}$ & $0.154^{* * *}$ & $0.256^{* * *}$ & 0.038 \\
Workers & $(0.345)$ & $(0.358)$ & $(0.43)$ & $(0.181)$ \\
Have Lower Performance Standards & $0.096^{* * *}$ & $0.154^{* * *}$ & $0.184^{* * *}$ & 0.044 \\
for Older Workers & $(0.286)$ & $(0.358)$ & $(0.382)$ & $(0.196)$ \\
Use Mixed Age Teams & $0.529^{* * *}$ & $\mathrm{~b}$ & $0.532^{* * *}$ & 0.116 \\
& $(0.487)$ & & $(0.491)$ & $(0.308)$ \\
Annual Turnover due to Retirements & $2.787^{* * *}$ & 2.77 & $4.533^{* * *}$ & 1.162 \\
& $(16.447)$ & $(8.064)$ & $(9.884)$ & $(8.936)$ \\
N & 1,634 & 56 & 82 & 6,560 \\
\hline
\end{tabular}

Notes: $* * * \mathrm{p}<0.01 ; * * \mathrm{p}<0.05 ; * \mathrm{p}<0.10$ in an independent samples $\mathrm{t}$ test of difference in means relative to Neither Practice group.

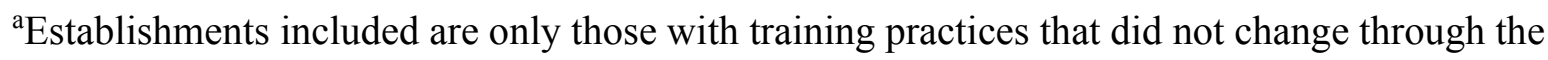
panel. An additional 770 establishments reported changes in training practices.

${ }^{b}$ Due to data use restrictions, data is not available for these practices in these establishments. 
Table 2. Relationship between Training Practices and Retirement Hazard Rates

\begin{tabular}{|c|c|c|c|c|}
\hline & $\begin{array}{l}(1) \\
\text { Men }\end{array}$ & $\begin{array}{c}(2) \\
\text { Women }\end{array}$ & $\begin{array}{l}(3) \\
\text { Men }\end{array}$ & $\begin{array}{c}(4) \\
\text { Women }\end{array}$ \\
\hline \multicolumn{5}{|l|}{ Training Practices } \\
\hline Involvement in Standard Training & $\begin{array}{l}-0.001 \\
(0.005)\end{array}$ & $\begin{array}{c}0.006 \\
(0.004)\end{array}$ & $\begin{array}{c}0.000 \\
(0.005)\end{array}$ & $\begin{array}{c}0.006 \\
(0.005)\end{array}$ \\
\hline Targeted Program & $\begin{array}{c}0.004 \\
(0.007)\end{array}$ & $\begin{aligned}-0.016^{*} \\
(0.009)\end{aligned}$ & $\begin{array}{c}0.004 \\
(0.007)\end{array}$ & $\begin{array}{r}-0.016^{*} \\
(0.009)\end{array}$ \\
\hline Training Participation & $\begin{array}{l}-0.000 \\
(0.000)\end{array}$ & $\begin{array}{l}-0.000 \\
(0.000)\end{array}$ & $\begin{array}{l}-0.000 \\
(0.000)\end{array}$ & $\begin{array}{l}-0.000 \\
(0.000)\end{array}$ \\
\hline Reporting $^{\mathrm{a}}$ & $\begin{array}{c}0.000 \\
(0.004)\end{array}$ & $\begin{array}{l}-0.001 \\
(0.003)\end{array}$ & $\begin{array}{c}0.000 \\
(0.004)\end{array}$ & $\begin{array}{l}-0.001 \\
(0.003)\end{array}$ \\
\hline Participation*Reporting $^{\mathrm{a}}$ & $\begin{array}{l}-0.000 \\
(0.000)\end{array}$ & $\begin{array}{c}0.000 \\
(0.000)\end{array}$ & $\begin{array}{l}-0.000 \\
(0.000)\end{array}$ & $\begin{array}{c}0.000 \\
(0.000)\end{array}$ \\
\hline \multicolumn{5}{|l|}{$\begin{array}{l}\text { Other Establishment Practice for Older } \\
\text { Workers }\end{array}$} \\
\hline Partial Retirement & & & $\begin{array}{c}-0.014 * * \\
(0.006)\end{array}$ & $\begin{array}{l}-0.005 \\
(0.006)\end{array}$ \\
\hline Special Equipment & & & $\begin{array}{c}0.000 \\
(0.007)\end{array}$ & $\begin{array}{c}0.001 \\
(0.005)\end{array}$ \\
\hline Lower Performance Targets & & & $\begin{array}{c}0.001 \\
(0.006)\end{array}$ & $\begin{array}{l}-0.005 \\
(0.006)\end{array}$ \\
\hline Mixed Age Teams & & & $\begin{array}{l}-0.003 \\
(0.003)\end{array}$ & $\begin{array}{l}-0.001 \\
(0.004)\end{array}$ \\
\hline Other Practices & & & $\begin{array}{c}0.010 \\
(0.011)\end{array}$ & $\begin{array}{c}0.009 \\
(0.007)\end{array}$ \\
\hline $\mathrm{N}$ & 522,939 & 236,992 & 522,939 & 236,992 \\
\hline
\end{tabular}

Notes: $* * * \mathrm{p}<0.01 ; * * \mathrm{p}<0.05 ; * \mathrm{p}<0.10$

${ }^{a}$ Establishments report total training participation as either number of individuals participating or number of incidences of training and we divide this figure by firm size to construct the Training Participation measure. Reporting is equal to 1 for establishments that report training as number of incidences per year instead of number of individuals trained. 
Figure 1. Changes in Retirement Hazard Rates Associated with Establishment Training Practices across the Market Wage Distribution, Marginal Effects after Regression for Women

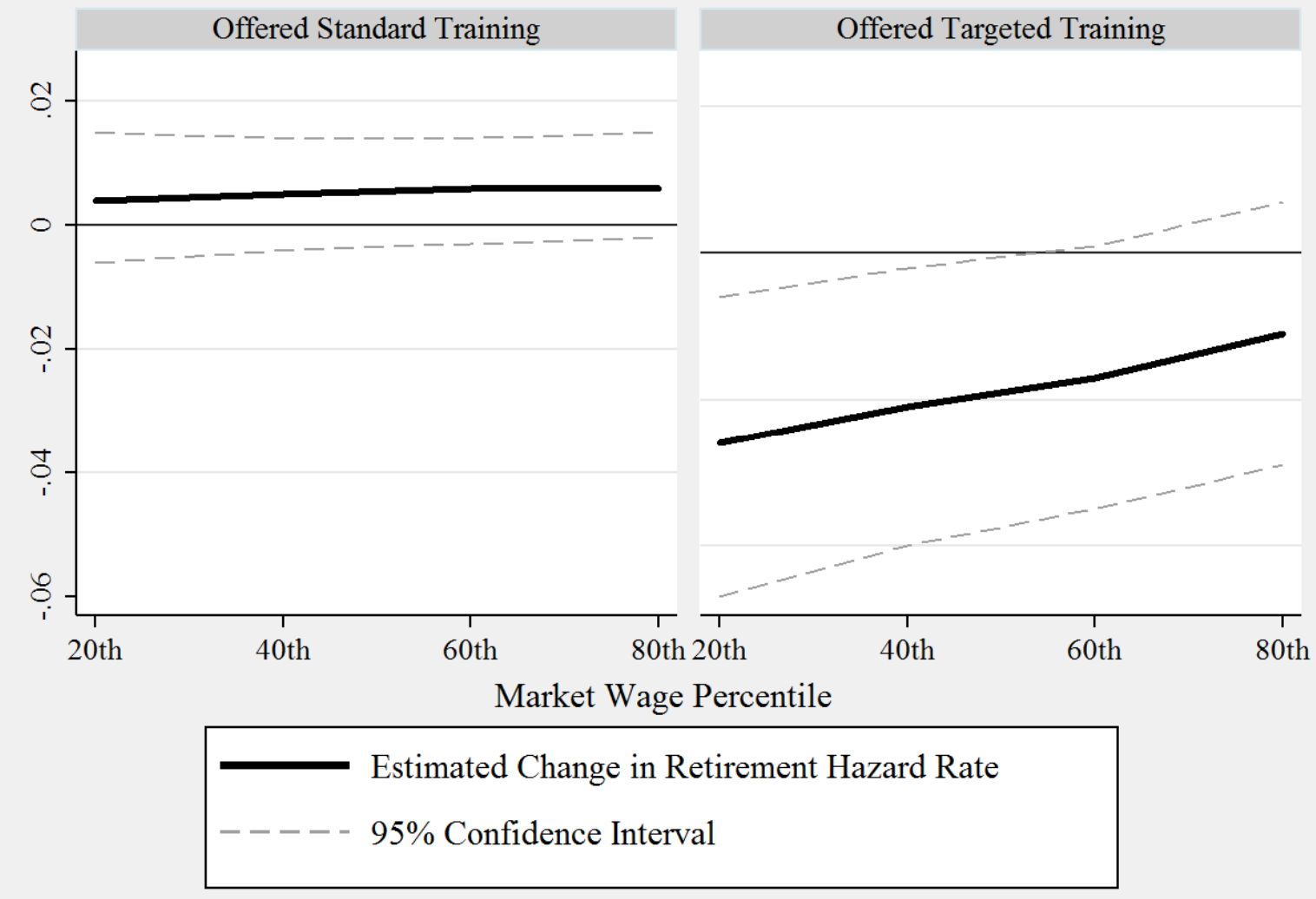


Figure 2. Changes in Retirement Hazard Rates Associated with Establishment Training Practices across the Market Wage Distribution, Marginal Effects after Regression for Men

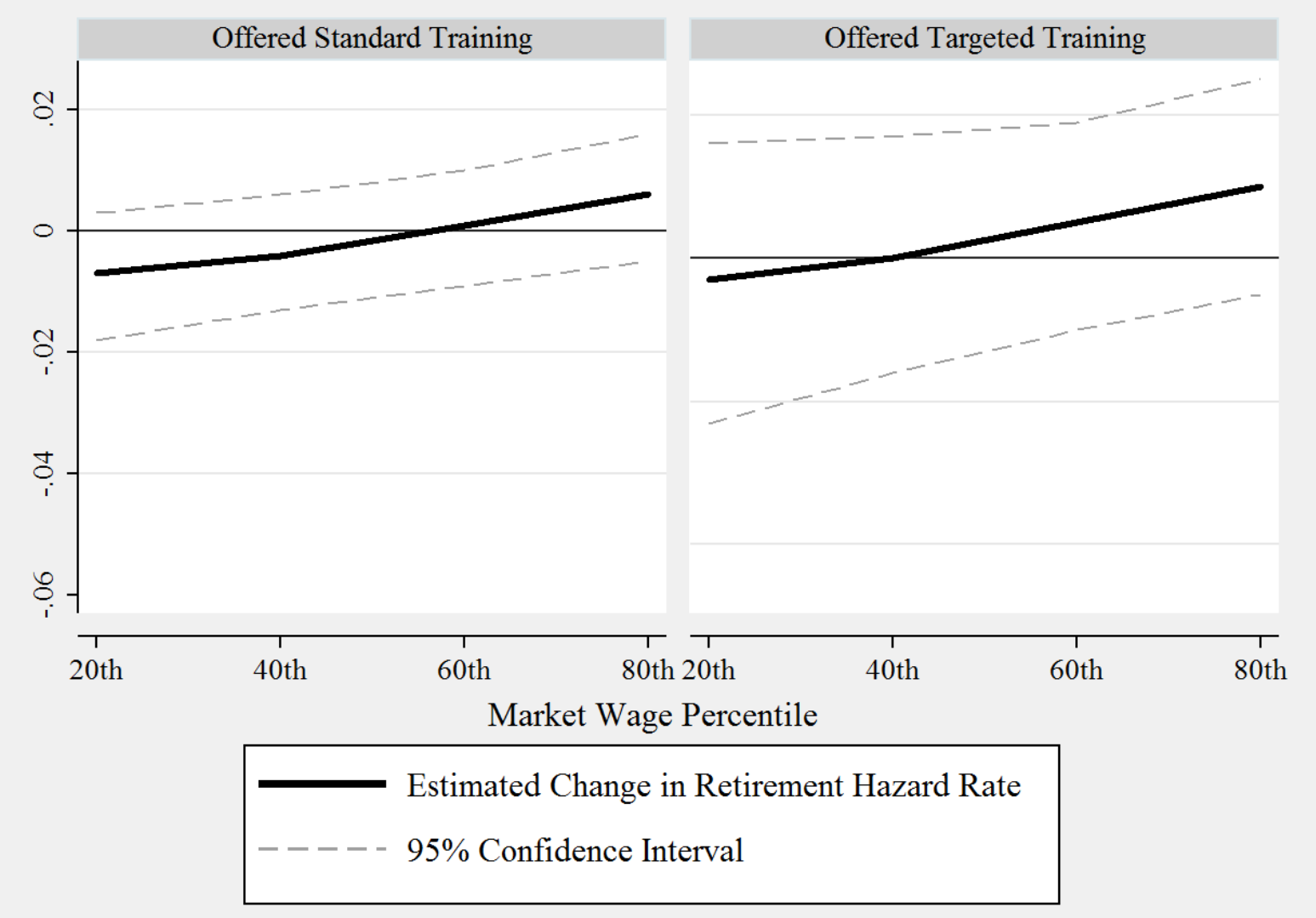


Figure 3. Changes in Retirement Hazard Rates Associated with Training Practices by Position in the Establishment Wage Distribution, Marginal Effects after Regression for Women

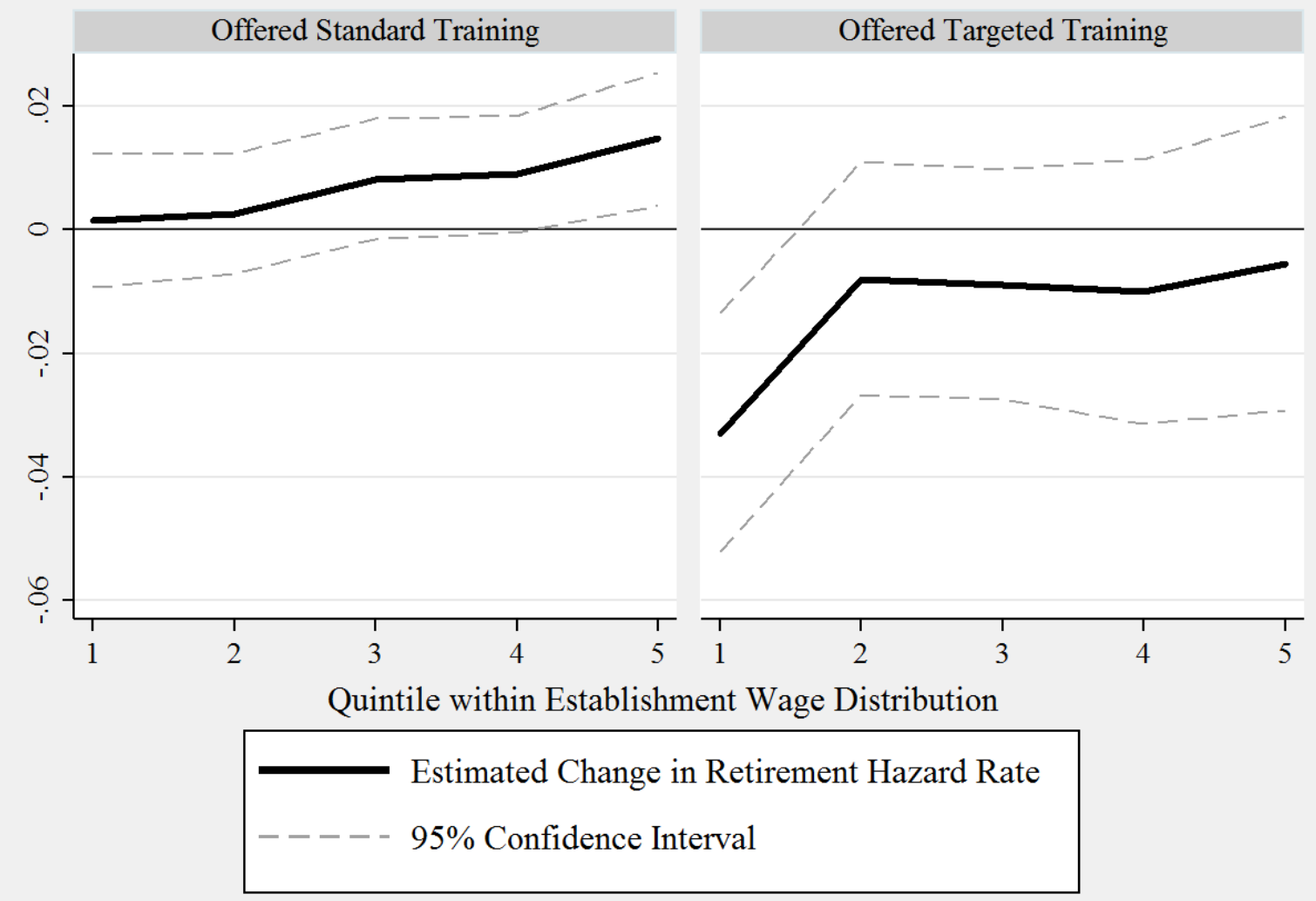


Figure 4. Changes in Retirement Hazard Rates Associated with Training Practices by Position in the Establishment Wage Distribution, Marginal Effects after Regression for Men

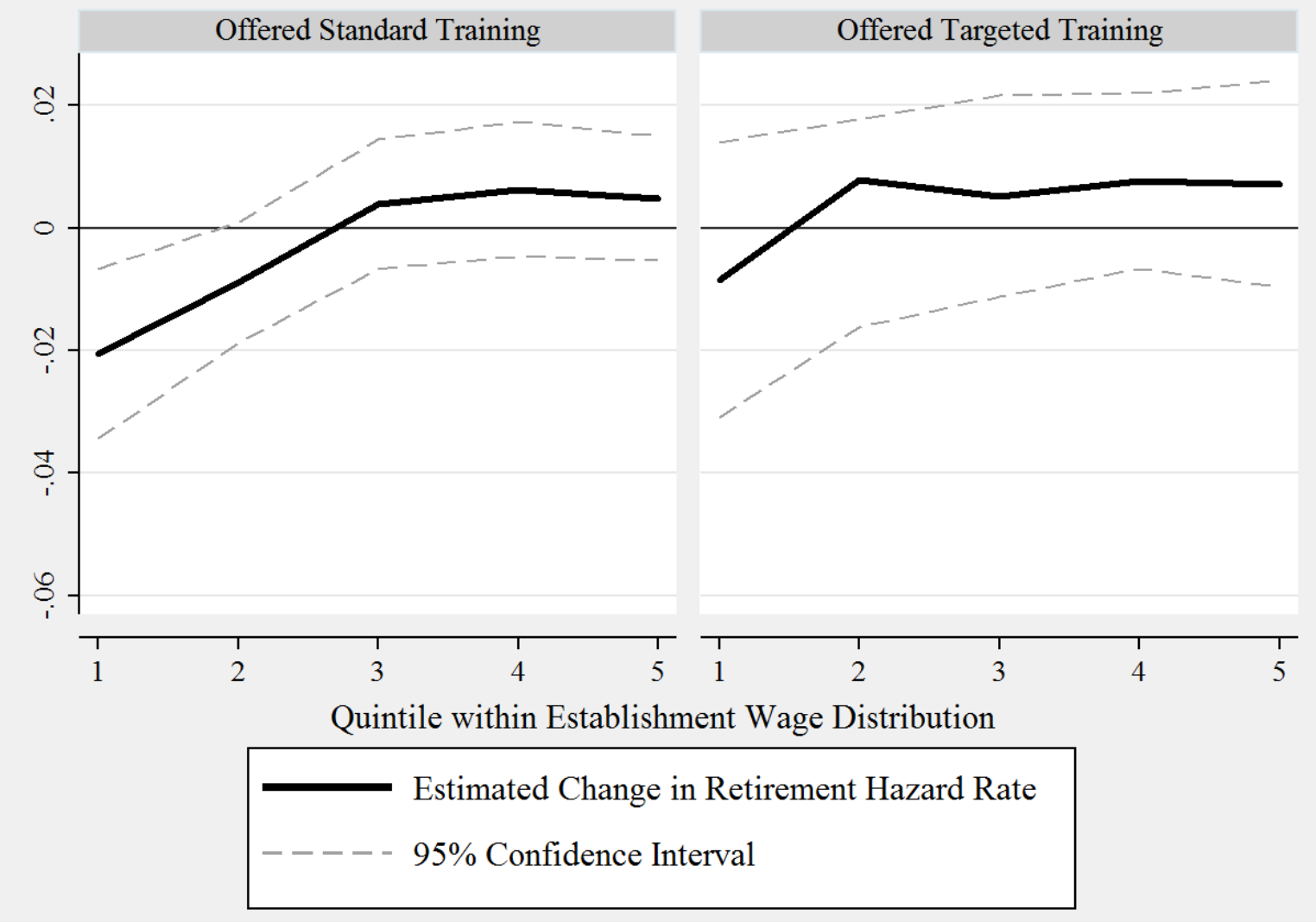


Table 3. Relationship between Establishment Training Practices and Individual Wage Levels, Growth, and Within Establishment Wage Mobility

\begin{tabular}{|c|c|c|c|c|}
\hline Dependent Variable: & $\ln$ (wage) & $\ln$ (wage) & $\begin{array}{c}\text { (3) } \\
\text { \% Change } \\
\text { in Wage }\end{array}$ & $\begin{array}{c}\text { (4) } \\
\text { Wage } \\
\text { Mobility } \\
\text { Indicator }\end{array}$ \\
\hline \multicolumn{5}{|l|}{ Panel A: Men } \\
\hline Standard & $\begin{array}{l}-0.002 \\
(0.004)\end{array}$ & $\begin{array}{c}0.004 * * \\
(0.002)\end{array}$ & $\begin{array}{l}2.004^{*} \\
(1.225)\end{array}$ & $\begin{array}{c}-0.024 * \\
(0.014)\end{array}$ \\
\hline Targeted & $\begin{array}{l}-0.015 \\
(0.016)\end{array}$ & $\begin{array}{c}0.004 \\
(0.004)\end{array}$ & $\begin{array}{c}-3.483^{*} \\
(1.848)\end{array}$ & $\begin{array}{c}0.053 \\
(0.046)\end{array}$ \\
\hline Training Participation & $\begin{array}{c}-0.000 * * * \\
(0.000)\end{array}$ & $\begin{array}{l}-0.000 \\
(0.000)\end{array}$ & $\begin{array}{l}-0.054^{*} \\
(0.032)\end{array}$ & $\begin{array}{c}-0.000 * \\
(0.000)\end{array}$ \\
\hline Reporting $^{\mathrm{b}}$ & $\begin{array}{c}0.018 * * * \\
(0.006)\end{array}$ & $\begin{array}{l}-0.001 \\
(0.002)\end{array}$ & $\begin{array}{c}-2.098 \\
(1.618)\end{array}$ & $\begin{array}{c}0.008 \\
(0.009)\end{array}$ \\
\hline Training Participation*Reporting ${ }^{\mathrm{b}}$ & $\begin{array}{l}-0.000 \\
(0.000)\end{array}$ & $\begin{array}{l}-0.000 \\
(0.000)\end{array}$ & $\begin{array}{c}0.052 \\
(0.036)\end{array}$ & $\begin{array}{l}-0.000^{*} \\
(0.000)\end{array}$ \\
\hline $\mathrm{N}$ & 520,203 & 520,203 & 119,738 & 119,798 \\
\hline \multicolumn{5}{|l|}{ Panel B: Women } \\
\hline Standard & $\begin{array}{c}0.023 * * * \\
(0.004)\end{array}$ & $\begin{array}{c}0.002 \\
(0.004)\end{array}$ & $\begin{array}{l}-0.022 \\
(0.786)\end{array}$ & $\begin{array}{c}-0.014 * * \\
(0.006)\end{array}$ \\
\hline Targeted & $\begin{array}{l}0.023^{*} \\
(0.012)\end{array}$ & $\begin{array}{l}-0.000 \\
(0.007)\end{array}$ & $\begin{array}{l}3.077^{*} \\
(1.622)\end{array}$ & $\begin{array}{l}0.020^{*} \\
(0.011)\end{array}$ \\
\hline Training Participation & $\begin{array}{c}0.000 \\
(0.000)\end{array}$ & $\begin{array}{c}0.000 \\
(0.000)\end{array}$ & $\begin{array}{l}-0.008 \\
(0.012)\end{array}$ & $\begin{array}{l}0.000^{*} \\
(0.000)\end{array}$ \\
\hline Reporting $^{\mathrm{b}}$ & $\begin{array}{c}0.018 * * * \\
(0.006)\end{array}$ & $\begin{array}{l}-0.004 \\
(0.003)\end{array}$ & $\begin{array}{c}1.103 \\
(1.281)\end{array}$ & $\begin{array}{l}-0.003 \\
(0.007)\end{array}$ \\
\hline Training Participation* Reporting ${ }^{\mathrm{b}}$ & $\begin{array}{l}0.000 * \\
(0.000)\end{array}$ & $\begin{array}{c}0.000 \\
(0.000)\end{array}$ & $\begin{array}{l}-0.007 \\
(0.021)\end{array}$ & $\begin{array}{c}-0.000 * * \\
(0.000)\end{array}$ \\
\hline $\mathrm{N}$ & 235,497 & 235,497 & 39,166 & 39,166 \\
\hline Establishment Fixed Effects & No & Yes & No & No \\
\hline
\end{tabular}

Notes: $* * * p<0.01 ; * * p<0.05 ; * p<0.10$

a'Wage mobility indicator is equal to 1 if the individual's wages in the next survey year are in a higher quintile within the establishment wage distribution than in the current survey year, and 0 otherwise.

${ }^{b}$ Establishments report total training participation as either number of individuals participating or number of incidences of training and we divide this figure by firm size to construct the Training Participation measure. Reporting is equal to 1 for establishments that report training as number of incidences per year instead of number of individuals trained. 
Appendix

Table A1. Full Sample Characteristics for Key Variables, Employee-Year Level

Mean

Standard

Deviation

Dependent and Key Independent Variables

\begin{tabular}{|c|c|c|}
\hline Retire & 0.06 & 0.23 \\
\hline Standard & 0.44 & 0.50 \\
\hline Targeted & 0.05 & 0.21 \\
\hline Training Participation (not normalized by firm size) & $2,237.87$ & $5,861.35$ \\
\hline Reporting & 0.55 & 0.50 \\
\hline \multicolumn{3}{|l|}{ Individual Characteristics } \\
\hline Individual Age & 55.12 & 3.71 \\
\hline Male & 0.69 & 0.46 \\
\hline Secondary Education without Vocational Training & 0.16 & 0.36 \\
\hline Secondary Education with Vocational Training & 0.69 & 0.46 \\
\hline Upper Secondary, without Vocational Training & 0.00 & 0.07 \\
\hline Upper Secondary, with Vocational Training & 0.03 & 0.16 \\
\hline Applied Sciences Degree & 0.05 & 0.23 \\
\hline University Degree & 0.07 & 0.26 \\
\hline Trainee & 0.00 & 0.01 \\
\hline Unskilled Worker & 0.19 & 0.40 \\
\hline Skilled Worker & 0.20 & 0.40 \\
\hline Master Craftsman & 0.02 & 0.15 \\
\hline Employee & 0.39 & 0.49 \\
\hline Freelancer & 0.00 & 0.02 \\
\hline Part Time $<50 \%$ of Full-Time & 0.02 & 0.15 \\
\hline Part Time $>50 \%$ of Full-Time & 0.17 & 0.37 \\
\hline Daily Wage, $€$ & 103.13 & 39.67 \\
\hline Wage Growth in Percentage Points & 0.06 & 1.02 \\
\hline Tenure, Years & 15.96 & 9.83 \\
\hline \multicolumn{3}{|l|}{ Establishment Characteristics } \\
\hline Average Daily Wage & 99.42 & 26.71 \\
\hline Share Unskilled Workers & 0.17 & 0.21 \\
\hline Annual Turnover due to Firing & 5.55 & 15.46 \\
\hline Annual Turnover due to Retirements & 35.30 & 114.34 \\
\hline Perceived Profitability, 6 Point Likert Scale & 3.76 & 1.50 \\
\hline Revenue, Billions $€$ & 3.34 & 18.50 \\
\hline Employment & $4,515.50$ & $10,666.85$ \\
\hline Partial Retirement Policy & 0.83 & 0.38 \\
\hline Have Special Equipment for Older Workers & 0.24 & 0.43 \\
\hline Have Lower Performance Standards for Older Workers & 0.15 & 0.35 \\
\hline Use Mixed Age Teams & 0.38 & 0.48 \\
\hline 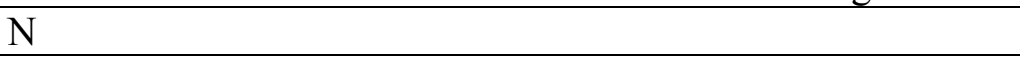 & \multicolumn{2}{|c|}{759,931} \\
\hline
\end{tabular}


Table A2. Relationship between Training Practices and Retirement Hazard Rates, Reporting Full Regression Results

\begin{tabular}{|c|c|c|c|c|}
\hline & $\begin{array}{l}\text { (1) } \\
\text { Men }\end{array}$ & $\begin{array}{c}(2) \\
\text { Women }\end{array}$ & $\begin{array}{l}(3) \\
\text { Men }\end{array}$ & $\begin{array}{c}(4) \\
\text { Women }\end{array}$ \\
\hline \multirow{6}{*}{ Training Participation } & -0.001 & 0.006 & 0.000 & 0.006 \\
\hline & $(0.005)$ & $(0.004)$ & $(0.005)$ & $(0.005)$ \\
\hline & 0.004 & $-0.016^{*}$ & 0.004 & $-0.016^{*}$ \\
\hline & $(0.007)$ & $(0.009)$ & $(0.007)$ & $(0.009)$ \\
\hline & -0.000 & -0.000 & -0.000 & -0.000 \\
\hline & $(0.000)$ & $(0.000)$ & $(0.000)$ & $(0.000)$ \\
\hline \multirow{2}{*}{ Reporting } & 0.000 & -0.001 & 0.000 & -0.001 \\
\hline & $(0.004)$ & $(0.003)$ & $(0.003)$ & $(0.003)$ \\
\hline Training & -0.000 & 0.000 & -0.000 & 0.000 \\
\hline Participation*Reporting & $(0.000)$ & $(0.000)$ & $(0.000)$ & $(0.000)$ \\
\hline \multirow[t]{2}{*}{ Total Employment } & $0.000 * *$ & $0.000 * * *$ & $0.000 * *$ & $0.000 * * *$ \\
\hline & $(0.000)$ & $(0.000)$ & $(0.000)$ & $(0.000)$ \\
\hline \multirow[t]{2}{*}{ Average Wage } & 0.000 & -0.000 & 0.000 & -0.000 \\
\hline & $(0.001)$ & $(0.000)$ & $(0.001)$ & $(0.000)$ \\
\hline \multirow[t]{2}{*}{ Perceived Profitability } & $-0.008 * *$ & -0.003 & $-0.008 * *$ & -0.003 \\
\hline & $(0.003)$ & $(0.002)$ & $(0.003)$ & $(0.002)$ \\
\hline \multirow[t]{2}{*}{ Revenue } & -0.000 & $-0.000 * *$ & -0.000 & $-0.000 * *$ \\
\hline & $(0.000)$ & $(0.000)$ & $(0.000)$ & $(0.000)$ \\
\hline Secondary Education & $0.004 * * *$ & $0.005 * * *$ & $0.004 * * *$ & $0.005 * * *$ \\
\hline with Vocational & $(0.002)$ & $(0.002)$ & $(0.002)$ & $(0.002)$ \\
\hline \multicolumn{5}{|l|}{ Training } \\
\hline \multirow{3}{*}{$\begin{array}{l}\text { Upper Secondary, } \\
\text { without Vocational } \\
\text { Training }\end{array}$} & 0.002 & 0.001 & 0.002 & 0.001 \\
\hline & $(0.004)$ & $(0.006)$ & $(0.004)$ & $(0.006)$ \\
\hline & \\
\hline Upper Secondary, with & 0.004 & $0.008 * *$ & 0.004 & $0.008 * *$ \\
\hline Vocational Training & $(0.003)$ & $(0.003)$ & $(0.003)$ & $(0.003)$ \\
\hline Applied Sciences & $0.006^{* *}$ & $0.011 * * *$ & $0.006^{*}$ & $0.011 * * *$ \\
\hline Degree & $(0.003)$ & $(0.004)$ & $(0.003)$ & $(0.004)$ \\
\hline \multirow[t]{2}{*}{ University Degree } & $0.007 * *$ & $0.018 * * *$ & $0.006^{* *}$ & $0.018^{* * *}$ \\
\hline & $(0.003)$ & $(0.003)$ & $(0.003)$ & $(0.003)$ \\
\hline \multirow[t]{2}{*}{ Unskilled Worker } & -0.127 & -0.000 & -0.127 & -0.000 \\
\hline & $(0.117)$ & $(0.056)$ & $(0.117)$ & $(0.056)$ \\
\hline \multirow[t]{2}{*}{ Skilled Worker } & -0.126 & -0.001 & -0.126 & -0.000 \\
\hline & $(0.117)$ & $(0.056)$ & $(0.117)$ & $(0.056)$ \\
\hline \multirow[t]{2}{*}{ Master Craftsman } & -0.104 & 0.024 & -0.104 & 0.025 \\
\hline & $(0.116)$ & $(0.057)$ & $(0.116)$ & $(0.057)$ \\
\hline \multirow[t]{2}{*}{ Employee } & -0.103 & 0.012 & -0.103 & 0.012 \\
\hline & $(0.116)$ & $(0.056)$ & $(0.116)$ & $(0.056)$ \\
\hline
\end{tabular}


Table A2, Continued.

\begin{tabular}{lcccc}
\hline Freelancer & -0.166 & -0.016 & -0.165 & -0.016 \\
& $(0.117)$ & $(0.059)$ & $(0.117)$ & $(0.059)$ \\
Part Time $<50 \%$ of & -0.099 & -0.016 & -0.098 & -0.016 \\
Full-Time & $(0.117)$ & $(0.056)$ & $(0.117)$ & $(0.056)$ \\
Part Time $>50 \%$ of & -0.085 & 0.002 & -0.085 & 0.002 \\
Full-Time & $(0.117)$ & $(0.056)$ & $(0.117)$ & $(0.056)$ \\
Tenure in Days & $-0.000^{* * *}$ & $-0.000^{* * *}$ & $-0.000^{* * *}$ & -0.000 \\
& $(0.000)$ & $(0.000)$ & $(0.000)$ & $(0.000)$ \\
Wages & $-0.001^{* * *}$ & $-0.001^{* * *}$ & $-0.001^{* * *}$ & -0.001 \\
& $(0.000)$ & $(0.000)$ & $(0.000)$ & $(0.000)$ \\
Partial Retirement & & & $-0.014^{* *}$ & -0.005 \\
& & & $(0.006)$ & $(0.006)$ \\
Special Equipment & & & 0.000 & 0.001 \\
& & & $(0.007)$ & $(0.005)$ \\
Lower Performance & & 0.001 & -0.005 \\
Targets & & $(0.006)$ & $(0.006)$ \\
Mixed Age Teams & & -0.003 & -0.001 \\
& & $(0.003)$ & $(0.004)$ \\
Other Older Worker & & & 0.010 & 0.009 \\
Practices & & & $(0.011)$ & $(0.007)$ \\
\hline Notes: & & & \\
\hline
\end{tabular}

Notes: $* * * \mathrm{p}<0.01 ; * * \mathrm{p}<0.05 ; * \mathrm{p}<0.10$ 
Table A3. Joint Effects of Training and Other Older Worker Practices

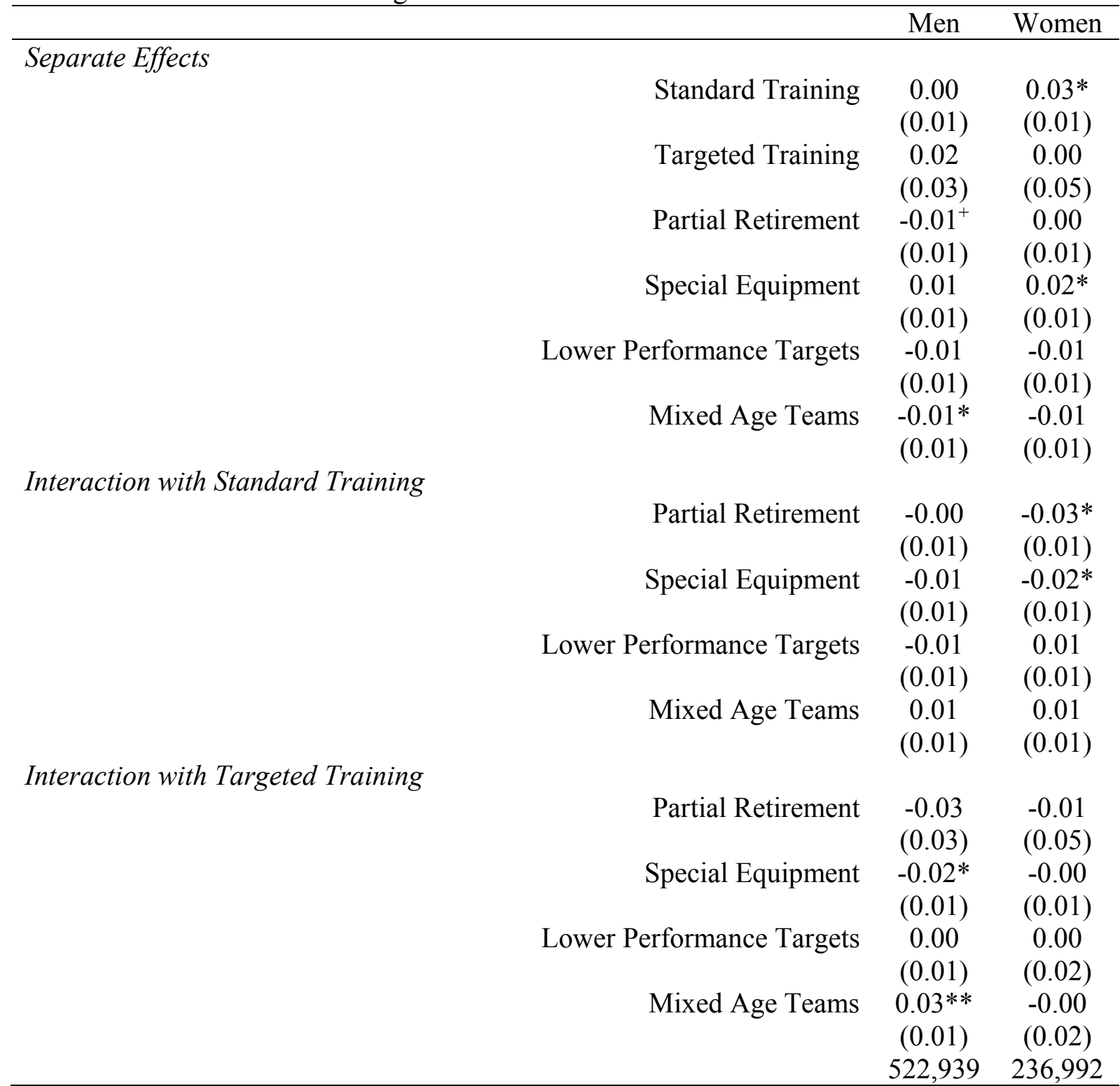

Notes: $* * * \mathrm{p}<0.01 ; * * \mathrm{p}<0.05 ; * \mathrm{p}<0.10$. Regressions contain all establishment and individual covariates from Equation [1] and include establishment fixed effects. 
Table A4. Influence of 2002 Establishment and Worker Characteristics on 2006 Practice Adoption

\begin{tabular}{|c|c|c|c|c|}
\hline & \multicolumn{2}{|c|}{$\begin{array}{c}\text { Standard Training Program } \\
\text { in } 2006\end{array}$} & \multicolumn{2}{|c|}{$\begin{array}{c}\text { Targeted Training Program } \\
\text { in } 2006\end{array}$} \\
\hline & Men & Women & Men & Women \\
\hline Retire in 2002 & $\begin{array}{l}-0.02 * \\
(0.01)\end{array}$ & $\begin{array}{l}-0.00 \\
(0.01)\end{array}$ & $\begin{array}{l}-0.00 \\
(0.00)\end{array}$ & $\begin{array}{l}0.01^{+} \\
(0.00)\end{array}$ \\
\hline Training Practices in 2002 & & & & \\
\hline Involvement in Standard Training & $\begin{array}{c}0.02 \\
(0.03)\end{array}$ & $\begin{array}{c}0.02 \\
(0.02)\end{array}$ & $\begin{array}{c}0.00 \\
(0.01)\end{array}$ & $\begin{array}{c}0.01 \\
(0.01)\end{array}$ \\
\hline Targeted Program & $\begin{array}{l}0.17^{+} \\
(0.10)\end{array}$ & $\begin{array}{c}0.08 \\
(0.06)\end{array}$ & $\begin{array}{c}0.04 \\
(0.04)\end{array}$ & $\begin{array}{c}0.04 \\
(0.03)\end{array}$ \\
\hline Training Participation, in $100 \mathrm{~s}$ & $\begin{array}{l}0.09^{*} \\
(0.04)\end{array}$ & $\begin{array}{c}0.05 \\
(0.03)\end{array}$ & $\begin{array}{l}0.04^{*} \\
(0.02)\end{array}$ & $\begin{array}{c}0.01 \\
(0.02)\end{array}$ \\
\hline $\begin{array}{r}\text { Participation Counted as } \\
\text { Incidences }\end{array}$ & $\begin{array}{c}0.01 \\
(0.04)\end{array}$ & $\begin{array}{c}0.00 \\
(0.00)\end{array}$ & $\begin{array}{l}-0.00 \\
(0.00)\end{array}$ & $\begin{array}{l}-0.00 \\
(0.01)\end{array}$ \\
\hline $\begin{array}{r}\text { Participation*Counted as } \\
\text { Incidences }\end{array}$ & $\begin{array}{c}0.04 \\
(0.09)\end{array}$ & $\begin{array}{c}0.02 \\
(0.05)\end{array}$ & $\begin{array}{c}0.01 \\
(0.05)\end{array}$ & $\begin{array}{c}0.00 \\
(0.00)\end{array}$ \\
\hline Other Establishment Characteristic & $\sin 2002$ & & & \\
\hline $\begin{array}{r}\text { Establishment Employment, } \\
1000 \mathrm{~s}\end{array}$ & $\begin{array}{c}0.00 \\
(0.00)\end{array}$ & $\begin{array}{c}0.00 \\
(0.00)\end{array}$ & $\begin{array}{c}0.00^{+} \\
(0.00)\end{array}$ & $\begin{array}{c}0.00 \\
(0.00)\end{array}$ \\
\hline Average Daily Wage, 100s of $€$ & $\begin{array}{l}-0.00 \\
(0.00)\end{array}$ & $\begin{array}{c}0.05 \\
(0.04)\end{array}$ & $\begin{array}{c}0.00 \\
(0.00)\end{array}$ & $\begin{array}{c}0.01 \\
(0.00)\end{array}$ \\
\hline Perceived Profitability & $\begin{array}{l}0.04 * * \\
(0.01)\end{array}$ & $\begin{array}{c}0.03 * * \\
(0.01)\end{array}$ & $\begin{array}{c}0.00 \\
(0.00)\end{array}$ & $\begin{array}{l}0.00^{*} \\
(0.00)\end{array}$ \\
\hline Revenue, millions $€$ & $\begin{array}{l}0.00^{*} \\
(0.00)\end{array}$ & $\begin{array}{c}-0.00^{* *} \\
(0.00)\end{array}$ & $\begin{array}{l}-0.00 \\
(0.00)\end{array}$ & $\begin{array}{l}-0.00 \\
(0.00)\end{array}$ \\
\hline Individual Characteristics & & & & \\
\hline $\begin{array}{r}\text { Secondary Education with } \\
\text { Vocational Training }\end{array}$ & $\begin{array}{l}-0.00 \\
(0.02)\end{array}$ & $\begin{array}{l}-0.00 \\
(0.01)\end{array}$ & $\begin{array}{l}-0.00 \\
(0.01)\end{array}$ & $\begin{array}{l}-0.01^{+} \\
(0.00)\end{array}$ \\
\hline Upper Secondary, without & -0.02 & -0.01 & -0.00 & -0.01 \\
\hline Vocational Training & $(0.02)$ & $(0.02)$ & $(0.01)$ & $(0.01)$ \\
\hline Upper Secondary, with & -0.01 & -0.00 & -0.00 & $-0.01^{+}$ \\
\hline Vocational Training & $(0.03)$ & $(0.01)$ & $(0.01)$ & $(0.00)$ \\
\hline Applied Sciences Degree & $\begin{array}{c}0.02 \\
(0.02)\end{array}$ & $\begin{array}{c}0.03 \\
(0.02)\end{array}$ & $\begin{array}{c}0.01 \\
(0.01)\end{array}$ & $\begin{array}{l}-0.01 \\
(0.00)\end{array}$ \\
\hline University Degree & $\begin{array}{c}0.01 \\
(0.03)\end{array}$ & $\begin{array}{c}0.00 \\
(0.01)\end{array}$ & $\begin{array}{c}0.00 \\
(0.01)\end{array}$ & $\begin{array}{l}-0.01 * \\
(0.00)\end{array}$ \\
\hline Unskilled Worker & $\begin{array}{l}-0.10 \\
(0.23)\end{array}$ & $\begin{array}{c}0.08^{* *} \\
(0.02)\end{array}$ & $\begin{array}{c}0.02 \\
(0.02)\end{array}$ & $\begin{array}{c}0.01 \\
(0.01)\end{array}$ \\
\hline Skilled Worker & $\begin{array}{l}-0.12 \\
(0.23)\end{array}$ & $\begin{array}{c}0.08^{* *} \\
(0.03)\end{array}$ & $\begin{array}{c}0.02 \\
(0.02)\end{array}$ & $\begin{array}{c}0.00 \\
(0.01)\end{array}$ \\
\hline Master Craftsman & $\begin{array}{l}-0.13 \\
(0.23)\end{array}$ & $\begin{array}{c}0.15^{* *} \\
(0.05)\end{array}$ & $\begin{array}{c}0.02 \\
(0.02)\end{array}$ & $\begin{array}{l}-0.01 \\
(0.01)\end{array}$ \\
\hline Employee & $\begin{array}{l}-0.15 \\
(0.23)\end{array}$ & $\begin{array}{l}0.05^{*} \\
(0.02)\end{array}$ & $\begin{array}{c}0.01 \\
(0.02)\end{array}$ & $\begin{array}{l}-0.00 \\
(0.01)\end{array}$ \\
\hline
\end{tabular}


Table A4, Continued

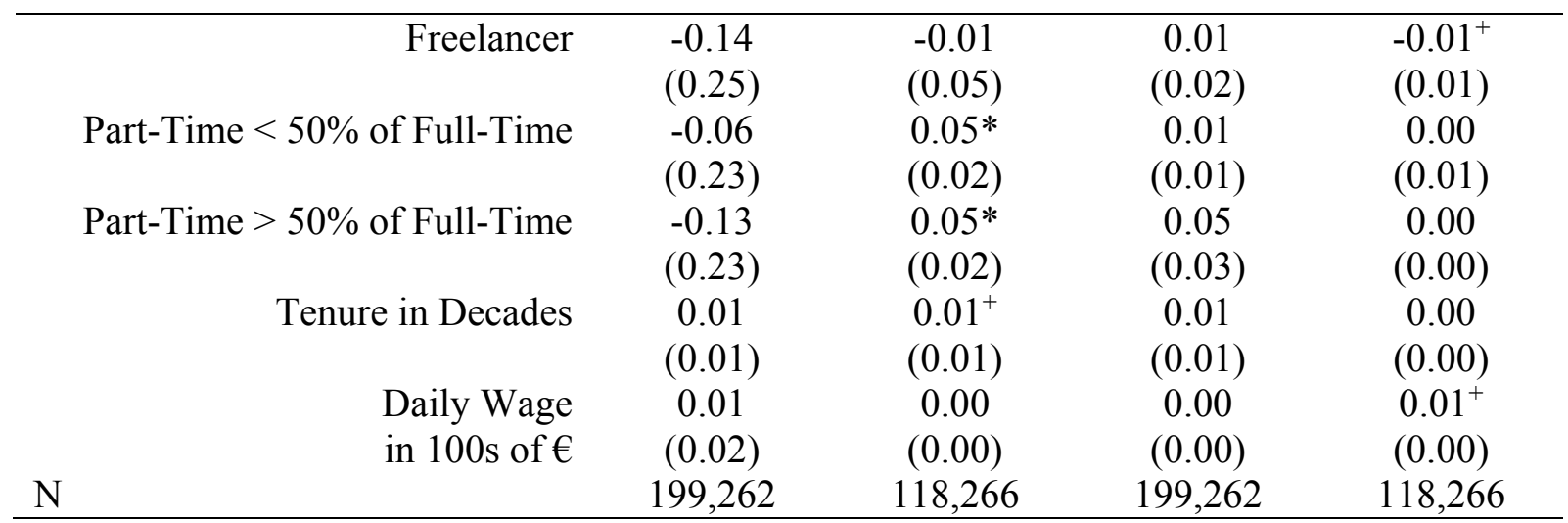

Notes: $* * * \mathrm{p}<0.01 ; * * \mathrm{p}<0.05 ; * \mathrm{p}<0.10$. 